\title{
Diagenetic Processes and Reservoir Heterogeneity in Salt-Encased Microbial Carbonate Reservoirs (Late Neoproterozoic, Oman)
}

\author{
Stephan Becker, ${ }^{1}$ Lars Reuning $\mathbb{D}^{1},{ }^{1}$ Joachim E. Amthor, ${ }^{2}$ and Peter A. Kukla ${ }^{1}$ \\ ${ }^{1}$ EMR Geological Institute, RWTH Aachen, Aachen, Germany \\ ${ }^{2}$ Shell Brasil Petróleo, Rio de Janeiro, Brazil \\ Correspondence should be addressed to Lars Reuning; lars.reuning@ifg.uni-kiel.de
}

Received 17 May 2019; Revised 24 August 2019; Accepted 7 September 2019; Published 4 November 2019

Academic Editor: Julien Bourdet

Copyright ( 2019 Stephan Becker et al. This is an open access article distributed under the Creative Commons Attribution License, which permits unrestricted use, distribution, and reproduction in any medium, provided the original work is properly cited.

\begin{abstract}
A common problem in dolomite reservoirs is the heterogeneous distribution of porosity-reducing diagenetic phases. The intrasalt carbonates of the Ediacaran-Early Cambrian Ara Group in the South Oman Salt Basin represent a self-sourcing petroleum system. Depositional facies and carbonate/evaporite platform architecture are well understood, but original reservoir properties have been modified by diagenesis. Some of the carbonate reservoirs failed to produce hydrocarbons at acceptable rates, which triggered this study. The extent of primary porosity reduction by diagenetic phases was quantified using point counting. To visualize the distribution of diagenetic phases on a field scale, we constructed 2D interpolation diagenesis maps to identify patterns in cementation. The relative timing of diagenetic events was constrained based on thin-section observations and stable isotope analyses. Near-surface diagenesis is dominated by reflux-related processes, leading to porosity inversion in initial highly porous facies and a patchy distribution of early cements. This strong diagenetic overprint of primary and early diagenetic porosity by reflux-related cements leads to a reduction of stratigraphic and facies control on porosity. Calcite was identified as a burial-related cement phase that leads to an almost complete loss of intercrystalline porosity and permeability. Bitumen is an important pore-occluding phase and time marker of the deep-burial realm. The stratigraphic position of the dolomite reservoirs embedded at the base of a salt diapir had a strong impact on its diagenetic development. The salt isolated the dolomites from external fluids, leading to a closed system diagenesis and the buildup of near lithostatic fluid pressures. In combination, these processes decreased the impact of further burial diagenetic processes. The study highlights that cement distribution in salt-encased carbonate reservoirs is mainly related to early diagenetic processes but can be very heterogeneous on a field scale. Further work is needed to implement these heterogeneities in an integrated numerical reservoir model.
\end{abstract}

\section{Introduction}

Large rock inclusions totally encased in salt (so-called rafts, floaters, or stringers) occur in many evaporite basins worldwide $[1,2]$. In Oman, these "stringers" constitute selfsourcing petroleum reservoirs [3-5].

There and in other salt giants such as the European Zechstein salt basin, these rock inclusions represent a significant drilling and safety challenge because of high overpressures and salt tectonic-related deformation and fragmentation of the reservoir [1,6-11]. The diagenetic characteristics of salt-encased reservoirs have been studied in the Late Permian (Zechstein) of the northern Netherlands [12], from a Jurassic clastic reservoir from the Shabwa Basin in Yemen [13] and in the Late Neoproterozoic to Early Cambrian Salt Basins of the Interior Oman [14] and the South Oman Salt Basin $[3,5,15-17]$. The latter provide diagenetic histories based on samples from different stratigraphic levels and burial depth. Our study is aimed at quantifying the diagenetic phases of a specific field-case study from the $\mathrm{A} 2 \mathrm{C}$ reservoir level in the South Oman Salt Basin (Figures 1-3). Understanding the diagenetic evolution within these stringers and its relation to salt tectonic deformation and burial history is considered important for understanding the evolution of their reservoir properties. Core observations, thin sections, bitumen reflectance, and stable isotopes were used to characterize the diagenetic processes within the salt-encased carbonate reservoirs. Distribution patterns of petrophysical 


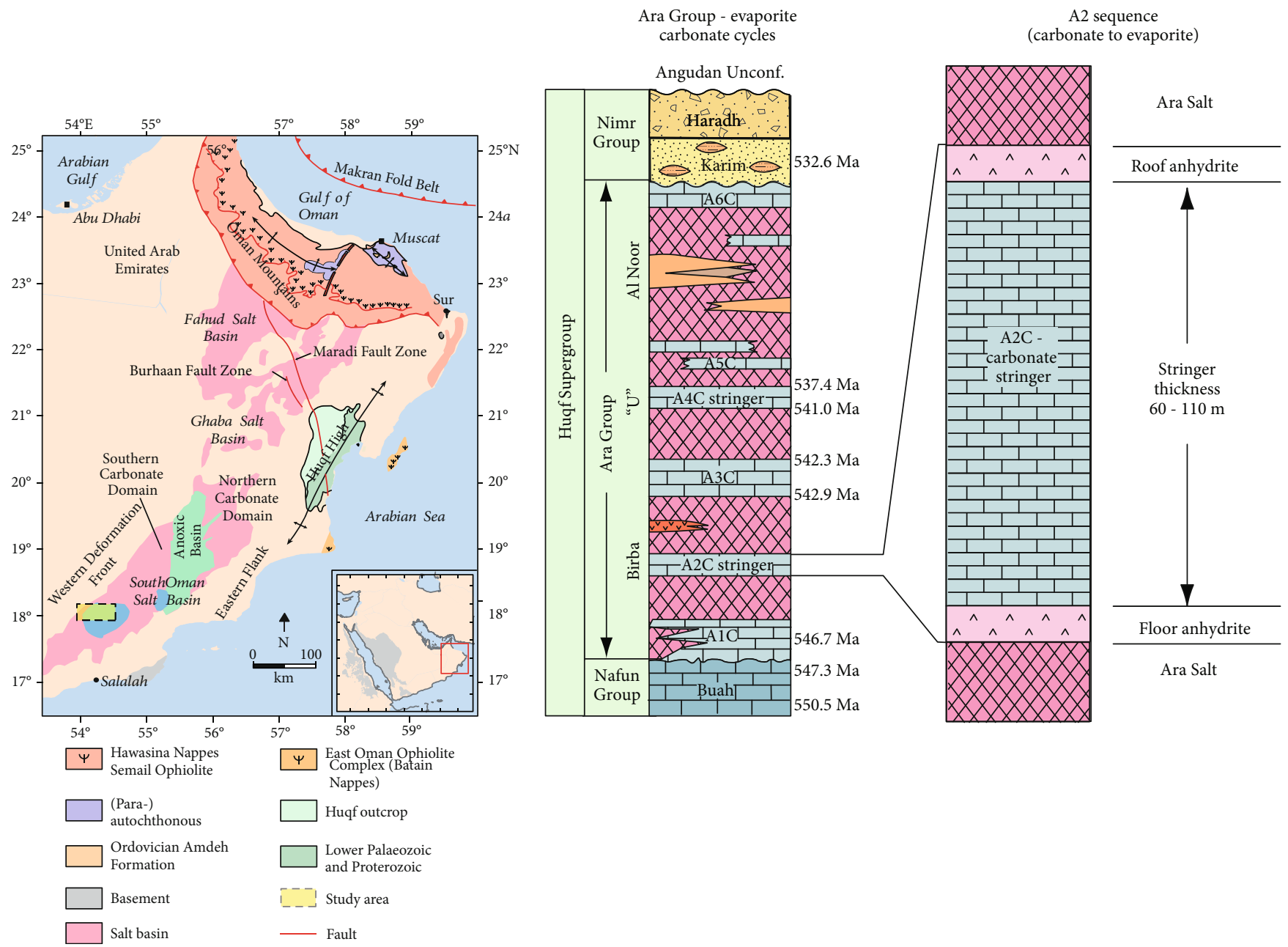

(a)

(b)

Figure 1: (a) Overview map of the Late Ediacaran to Early Cambrian salt basins of interior Oman (left part; modified after [14, 25]). The study area (marked by the yellow rectangle) is located in the southwestern part of the South Oman Salt Basin. (b) Geochronology and lithostratigraphy were adapted from Sharland et al. [73], Bowring et al. 2001, Allen [18], and Al-Husseini [74]. The lithostratigraphic composite log on the right (not to scale) shows the six carbonate to evaporite sequences of the Ara Group.

properties and diagenetic phases were visualized using field scale maps, giving insights into the heterogeneity of these parameters in the reservoir.

\section{Geological Setting}

The South Oman Salt Basin is one of the three Late Neoproterozoic to Early Cambrian subsurface salt basins of the interior Oman. They belong to a belt of restricted evaporitic basins, which span from Oman to Iran (Hormuz Salt) and Pakistan (Salt Range) and further to the East Himalaya [16, 18]. The western margin of the South Oman Salt Bain is represented by the "Western Deformation Front" (Figure 1), a structurally complex zone with transpressional characteristics [19]. The eastern margin is constituted by the so-called "Eastern Flank" (Figure 1), a structural high [20]. The sedimentation of the Huqf Supergroup from the Late Neoproterozoic until the Early Cambrian (approximately $725-530 \mathrm{Ma}$ ) onto the crystalline basement represents the initial basin fill [21]. Cyclic evaporate-carbonate deposits dominate the Ediacaran to
Early Cambrian Ara Group that, together with the siliciclastic Nimr Group, form the uppermost part of the Huqf Supergroup (Figure 1). Radiometric dating of ash beds confines the age of the Ara Group between 547 and $540 \mathrm{Ma}$, encompassing the Precambrian to Cambrian boundary [22, 23]. During deposition of the Ara Group, the basin was subdivided into three N-S trending paleogeographic domains. The Northern and Southern Carbonate Domains were separated by a deeper basin with a water depth of up to several hundred meters $[16,20]$. At least six cycles of interlayered carbonates and evaporites were deposited, termed A1 to A6 (Figure 1(b)) from bottom to top [3,21]. Salinity increase led to the deposition of a carbonate-sulfate-halite succession, turning into a halite-sulfate-carbonate sequence during the following sea level rise and highstand [16, 24, 25]. These carbonates formed partially isolated platforms that were broken up during halokinesis and are now completely encased in evaporites. In the Southern Carbonate Domain (Figure 1(a)), these carbonates form two geographically defined groups, the Birba and Harweel clusters (Figure 1(b)). The thickness 




Figure 2: Cross section from WSW to ENE through the working area of the South Oman Salt Basin. Facies, sequence boundaries, and flooding surfaces are indicated. Modified after Grotzinger and Rawahi [15] and Smodej et al. [26].

of the Ara Salt varies between $10 \mathrm{~m}$ and $150 \mathrm{~m}$ in the A1 to A4 cycles and can exceed $1000 \mathrm{~m}$ in the halokinetically more strongly deformed A5 and A6 interval [24]. The sulfate layers encasing the $20-220 \mathrm{~m}$ thick carbonate units, the so-called floor and roof anhydrites (Figures 1 and 2), are up to $30 \mathrm{~m}$ thick. Bromine geochemistry of the Ara Salt $[5,24]$ and the presence of marine fossils within the carbonate intervals [22] clearly indicate a seawater source for the Ara evaporites. The gypsum, later transformed to anhydrite (Figure 1(b)), formed in shallow hypersaline salinas [24]. The carbonate part of the A2 interval, the so-called A2C, of the Harweel cluster (Figure 1(b)), constitutes a broad isolated platform of several tens of $\mathrm{km}$ in width and at least several tens of meters in depositional relief [15]. The carbonate platform is composed of five sequences (Figure 2; $[3,15]$ ) that can be grouped in a lower platform (sequences 1 and 2) and an upper backstepped platform (sequences 3-5). The marine carbonates are dominated by microbial laminites. Generally, shallow-water grainstones, thrombolites, and peritidal facies are characterized by relatively high primary porosity whereas deeper ramp and downslope mudstones show poor reservoir quality [15]. The preservation of depositional or very early diagenetic microcrystalline dolomites in microbialite facies leads to generally high intercrystalline microporosities [26]. Due to a combination of depositional and diagenetic factors, the crinkly laminites from the deeper ramp form a major reservoir facies in the $\mathrm{A} 4 \mathrm{C}$ interval [25] but are characterized by strongly reduced porosities in other intervals [15].

During highstands, source rocks formed in the deeper, periodically anaerobic to dysaerobic parts of the basin [16]. The existence of A-norsterane biomarkers unequivocally confirms that the hydrocarbon accumulations originate from within the Ara Group [27]. The stringer play of the South Oman Salt Basin thus represents a self-charging and selfcontained petroleum system.

Subsequent deposition of continental siliciclastics mainly derived from the uplift and erosion along the Western Deformation Front on the mobile Ara Salt led to strong salt tectonic movements [28]. Differential loading formed clastic pods and salt diapirs, which led to folding and further fragmentation of the carbonate platforms into isolated stringers 


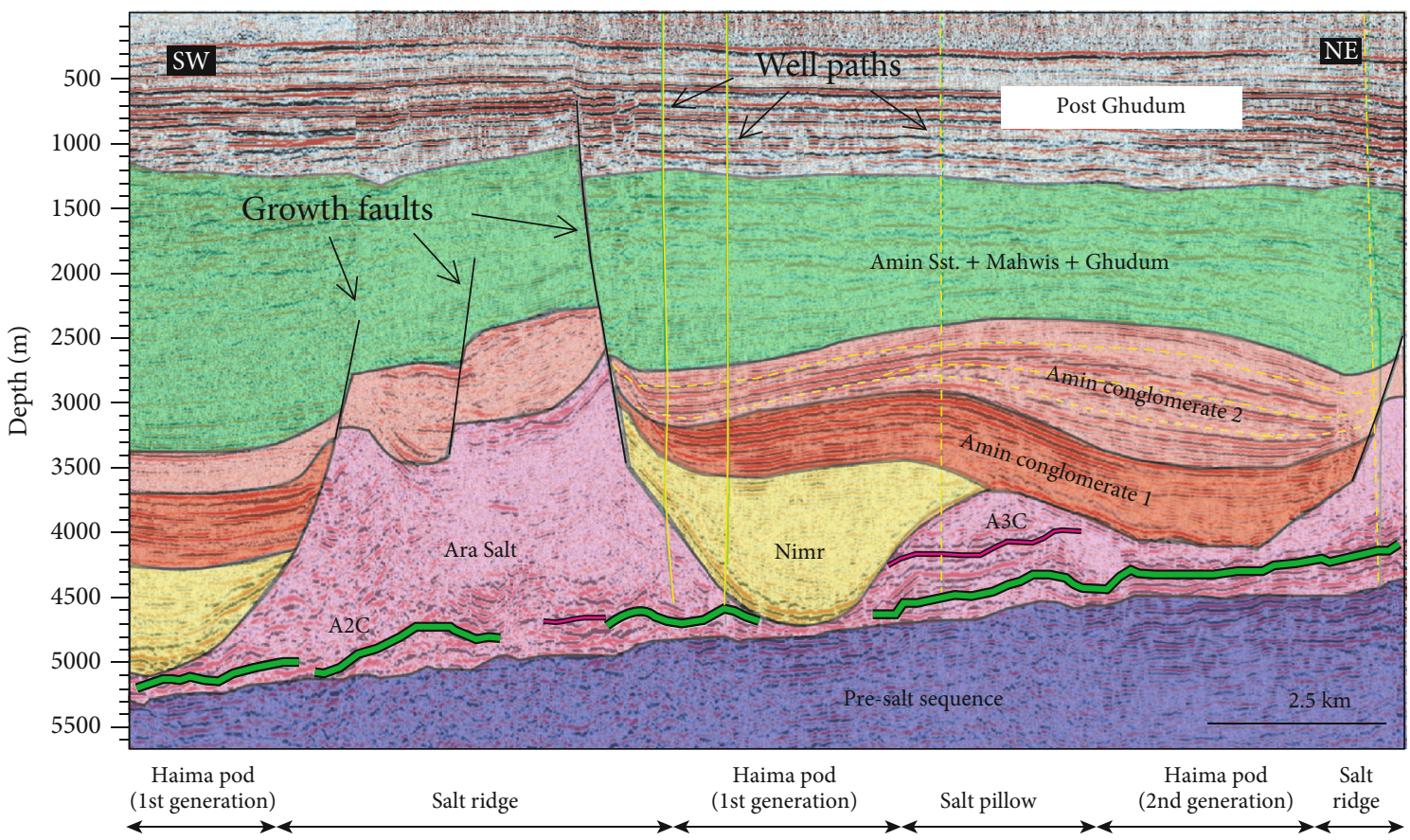

Figure 3: Interpretation of a seismic line crossing the study area (modified from [7]). The position of the line is shown in Figure 4. The formation of salt pillows and ridges is caused by passive downbuilding of the siliciclastic minibasins leading to folding and fragmentation of salt and stringers. Two generations of minibasins were identified: Minibasins of the first generation were formed during the deposition of the Nimr. A minibasin of the second generation was formed by passive downbuilding of the lower Humaid Mahatta Group.

floating in the Ara Salt (Figure 3). Finite element models (FEM) indicate that only $50-100 \mathrm{~m}$ differential load is needed for the $1^{\text {st }}$ breakages of the stringer [8]. Early stages of halokinesis started already in the Early Cambrian with deposition of the siliciclastic Nimr Group, sourced from the uplifted basement high in the Western Deformation Front (Figure 1(a)). The main phase of salt tectonic movements continued during the deposition of the lower part of the Haima Supergroup (Mahatta Humaid Group) until salt ridge rise could not keep pace with the massive sedimentation of the Early Ordovician Ghudun Formation. Later halokinetic movements because of reactivation of basement faults or salt dissolution were of only local importance [28].

\section{Materials and Methods}

More than 400 samples from nine wells were used for thinsection preparation (Figure 4). All thin sections were stained with Alizarin Red $\mathrm{S}$ to distinguish between dolomite and calcite. Ethane diol (Ethylene glycol $\mathrm{C} 2 \mathrm{H} 6 \mathrm{O} 2 \geq 99.5 \%$, p.a.) was used for cooling and lubrication during thin-section preparation to prevent the solution of halite. Point counting (min. 300 points) was used to quantify sedimentary and diagenetic phases such as allochems and matrix, authigenic cement phases, and pore types. The point count error for the modal percentage of a phase in an individual thin section was calculated using the equation of van der Plas \& Tobi [29]. For generation of the cement distribution maps, the cements in matrix porosities and fractures were treated separately. This dataset was combined with preexisting point counting results from the same and six additional wells (Figure 4). This data and sequence stratigraphic interpretations generated by Badley Ashton were provided by Petroleum Development of Oman (PDO). Using this data, maps of the spatial distribution of permeability, porosity, and diagenetic phases were created for the entire reservoir and for each of its five sequences (Figure 2). A similar workflow was presented previously by Nader et al. [30], who suggested these spatial distribution maps as a mean to quantify reservoir heterogeneities and an important step towards the construction of integrated numerical reservoir models. All spatial distribution maps show the modal cement values as percentage of the total rock volume. Fluid inclusions were studied petrographically on standard thin sections using a fluid inclusion (FI) assemblage approach, defining the most finely discriminated event of fluid inclusion entrapment [31]. Cathodoluminescence (CL) microscopy was used were applicable to identify recrystallization or healed fractures. Fluid inclusions forming trails were generally not interpreted as primary since their paragenetic relationship is often doubtful. The system HC-1 LM was used for cathodoluminescence microscopy. Carbon and oxygen isotopes $\left(\delta^{18} \mathrm{O}, \delta^{13} \mathrm{C}\right)$ were measured at the GEOMAR, Kiel (Germany). Average standard deviation based on analyses of a reference standard is $<0.07 \%$ o V-PDB or $\delta^{18} \mathrm{O}$ and $<0.03 \%$ V-PDB for $\delta^{13} \mathrm{C}$. The sulfur isotopes $\left(\delta^{34} \mathrm{~S}\right)$ of anhydrite were measured on a Thermo Finnigan Delta Plus equipped with an Elemental Analyzer (EA-IRMS). Approximately $200 \mu \mathrm{g}$ of finely ground sulfate was homogenously mixed with an equal amount of vanadium pentoxide and placed in a tin capsule for subsequent automated combustion and isotope measurement. Reproducibility was generally better than $+/-0.3 \%$ V-CDT. 


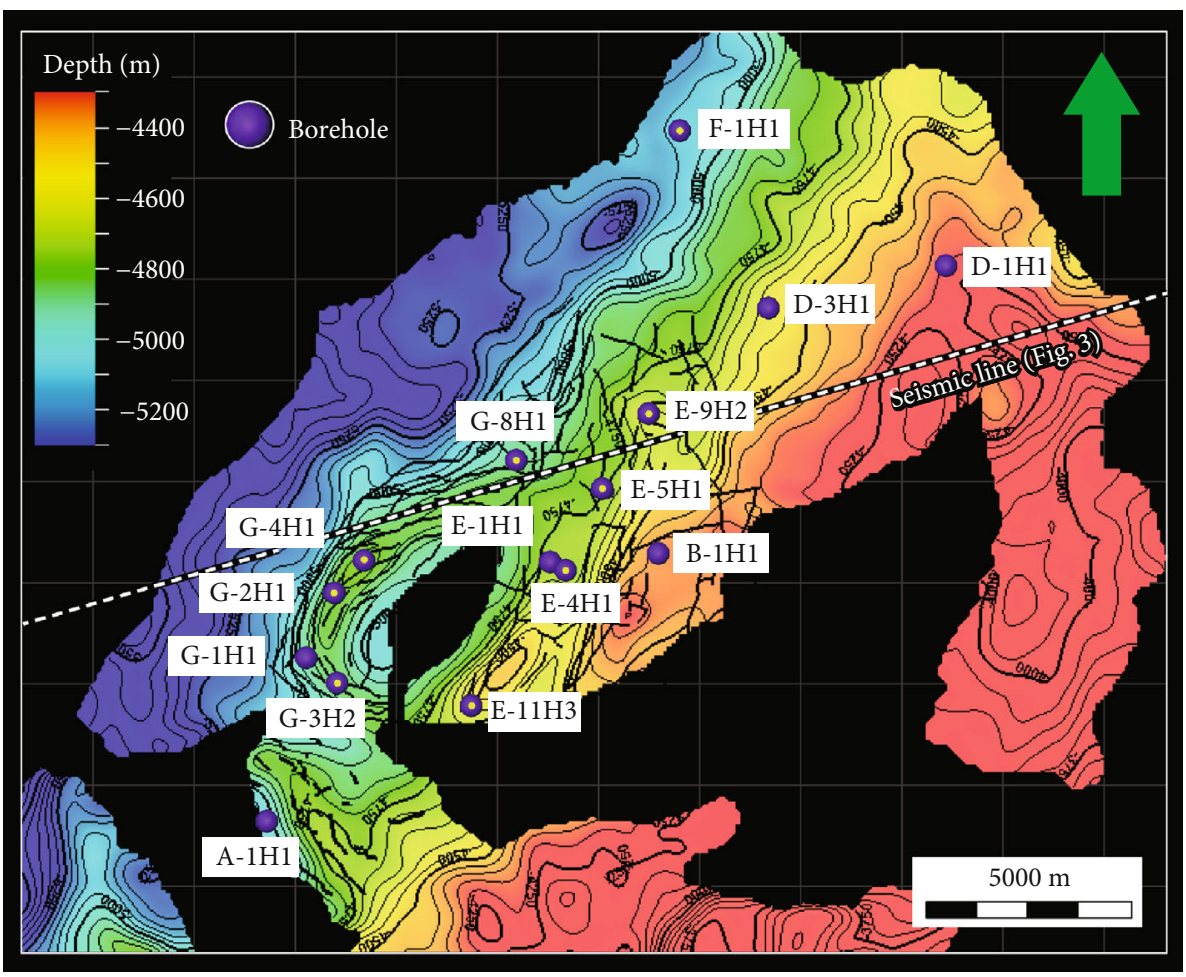

FIGURE 4: Contour map of the studied A2C interval. The position of wells and the interpreted seismic line presented in Figure 3 are indicated. Point counting data for all wells were generated by Badley Ashton and provided by Petroleum Development of Oman (PDO). Additional point counting data for nine of these wells, indicated by central white dot, was generated for this study.

Accuracy was monitored with lab standards and international reference materials (IAEA S1, S2, S3, NBS 127).

Bitumen reflectance analyses (min. 100 points) were performed at a magnification of 500x using a Zeiss Axio Imager microscope for incident light equipped with a tungstenhalogen lamp $(12 \mathrm{~V}, 100 \mathrm{~W})$, a 50x/0.85 Epiplan-NEOFLUAR oil immersion objective, and a $546 \mathrm{~nm}$ filter. Zeiss immersion oil (ne $=1.518 ; 23^{\circ} \mathrm{C}$ ) and mineral standards of known reflectance were used for calibration. Data are processed using the DISKUS Fossil software. The corresponding vitrinite reflectance (VRr) was calculated using the linear equation of Jacob [32]. The maximum burial temperature $\left(T_{\text {peakburial }}\right)$ was calculated from the VRr using the equation of Barker \& Pawlewicz [33]. For further details on the applied methods, see Becker et al. [34].

\section{Results}

The most abundant pore-reducing phases are dolomite (Figures 5(a), 5(b), 5(e), 6, and 7), anhydrite (Figures 5(d), $5(\mathrm{~g}), 6$, and 7), and reservoir bitumen (Figures 5(a) and $5(\mathrm{~h}))$. Over the entire reservoir, dolomite cement ranges between 0 and $28.9 \%$ with an average of $4.1 \%$. Anhydrite is slightly less abundant with a range from 0 to $12.9 \%$ and an average of $3.0 \%$, while pore plugging solid bitumen ranges between 0 and $18.7 \%$, with an average of $1.8 \%$. The abundance of halite cement is highly variable with depth in core and between wells (Figures 6-8). Halite cement abundance varies between 0 and $42.7 \%$, with an average of $1.5 \%$. Calcite cement is volumetrically only of minor importance with a range from 0 to $14.3 \%$ and an average of only $0.6 \%$. The distribution of diagenetic phases and petrophysical properties was plotted downhole and on spatial distribution maps (Figures 6-8). Nearly 66\% of the matrix porosity was filled with diagenetic phases, reducing the averaged modal porosity from $14.3 \%$ (Figure $7(\mathrm{~d})$, "open+filled" matrix porosity) to $5.0 \%$ (Figure 7(e), total modal porosity). Exemplarily, the spatial distribution maps of key diagenetic phases are shown for the entire carbonate stringer (Figure 6) and sequence 5 (Figure 7). Sequence 5 was selected since it is directly overlain by evaporite rocks (Figures 2 and 6) and therefore can be used best to investigate the influx of refluxing brines from the evaporitic sequence above. Typically, the porosity in carbonates below the evaporites is nearly completely plugged by halite and dolomite cement if their textures are permeable such as grain-/packstones and boundstones (Figures 6, 8(a), and $8(\mathrm{c}))$. In contrast to halite, which occurs only as a cement phase of minor importance in other wells, dolomite cement is an important porosity-reducing phase across the entire northernmost part of the field (Figures 7 and 8). In sequence 5 , anhydrite predominantly reduces the porosity along a north-south trend below the Haima pod (Figure 8). The permeability for a given porosity is generally high, where vuggy pores dominate the pore system indicating that the vugs are at least partially connected (Figures 6-8). Despite its low abundance, calcite cement can have a strong influence on permeability, since it often completely occludes the intercrystalline pores of the dolomite matrix (Figures 5(f) and 6). Cross-cutting relationships between diagenetic phases were used to reconstruct the relative timing of diagenetic events, 


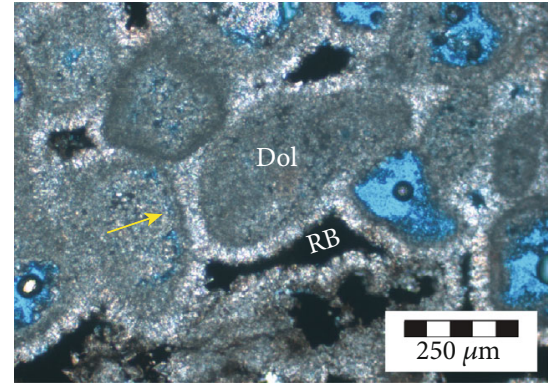

(a)

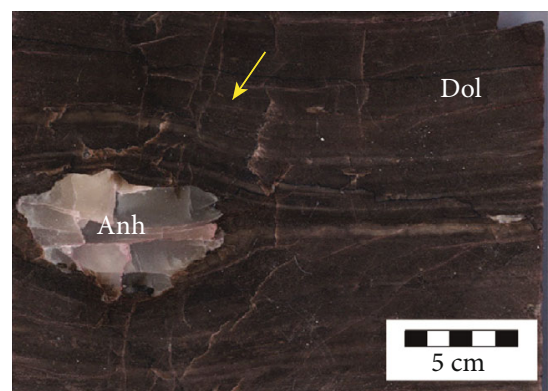

(c)

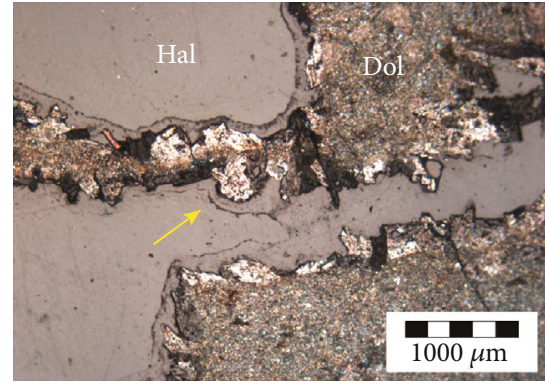

(e)

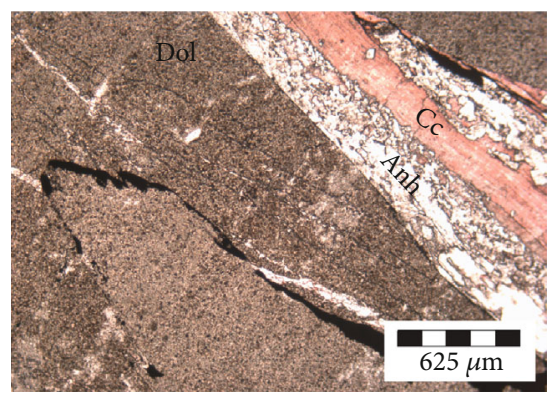

(g)

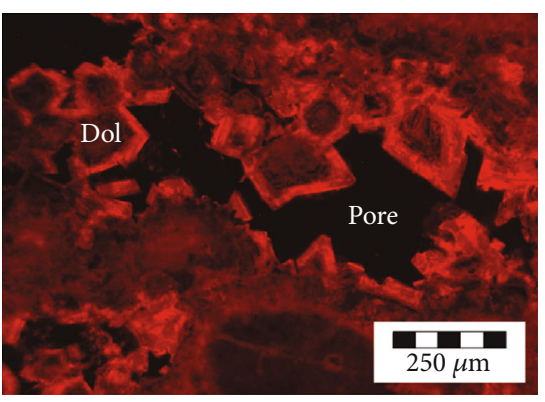

(b)

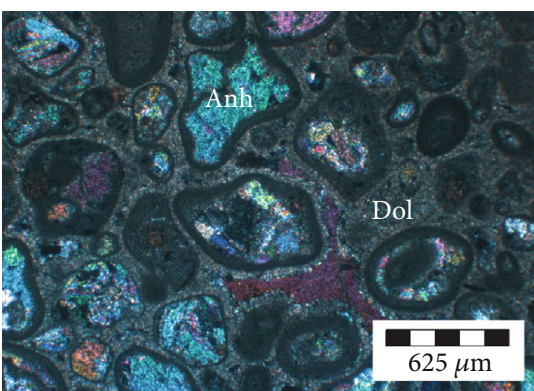

(d)

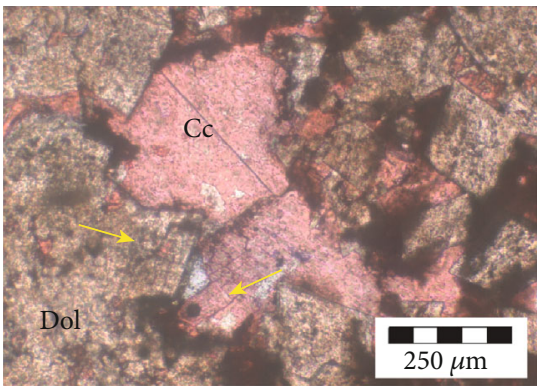

(f)

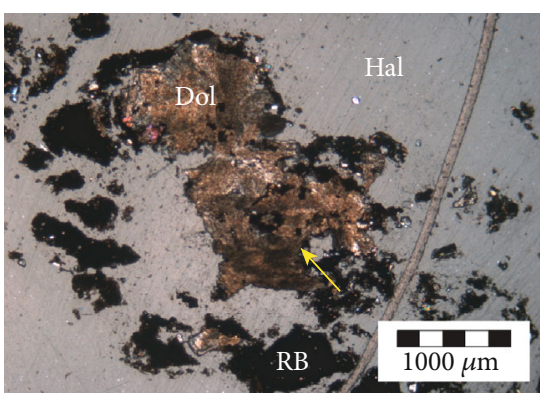

(h)

Figure 5: Diagenetic products observed in thin sections and on core: (a) G-2H1 (4950.77 m): columnar, isopachous cement around allochems (yellow arrow) and local reservoir bitumen $(\mathrm{RB})$ within the remaining interparticle porosity. The columnar, isopachous cement likely was formed during early marine diagenesis and the remaining interparticle porosity was during further (deep burial) diagenesis occluded with reservoir bitumen (ppl, 100x). (b) G-8H1 (4951.33 m): dolomite cements (Dol) in a fenestral pore (cathodoluminescence, 100x). (c) E-5H1 $(4779.73 \mathrm{~m})$ : anhydrite nodule (Anh) with compactional drape (yellow arrow) and relic inclusions of dolomite (observed in thin sections). The replacive nodule, formed prior to physical compaction as indicated by the compactional drape. The position of the sample in the vertical profile of the well is indicated in Figure 6 (core slab). (d) E-4H1 (4797.34 m): anhydrite cements (Anh) within moldic porosity outlined by micritic envelopes (xpl, 40x). (e) G-2H1 $(4884.33 \mathrm{~m})$ : dolomite (Dol, yellow arrow) cement predating halite cements (Hal) is common in reservoir facies with high primary porosity (ppl, 25x). (f) G-8H1 (4984.20 m): calcite cement (Cc) in intercrystalline porosity, postdating replacive dolomite matrix (Dol) and overgrowth of euhedral dolomite cements (upper yellow arrow). Oil inclusions inside (lower yellow arrow) indicate a precipitation of calcite in the deep burial realm during/after oil migration (ppl, 100x). (g) G-3H2 (4941.49 m): reservoir bitumen-lined stylolite with anhydrite- and calcite-filled tension gash (ppl, 40x). (h) G-2H1 (4889.35 m): inclusions of angular reservoir bitumen and reservoir bitumen-impregnated dolomite (yellow arrow) indicate that halite precipitated after solid bitumen generation ( $\mathrm{ppl}, 25 \mathrm{x}$ ). 


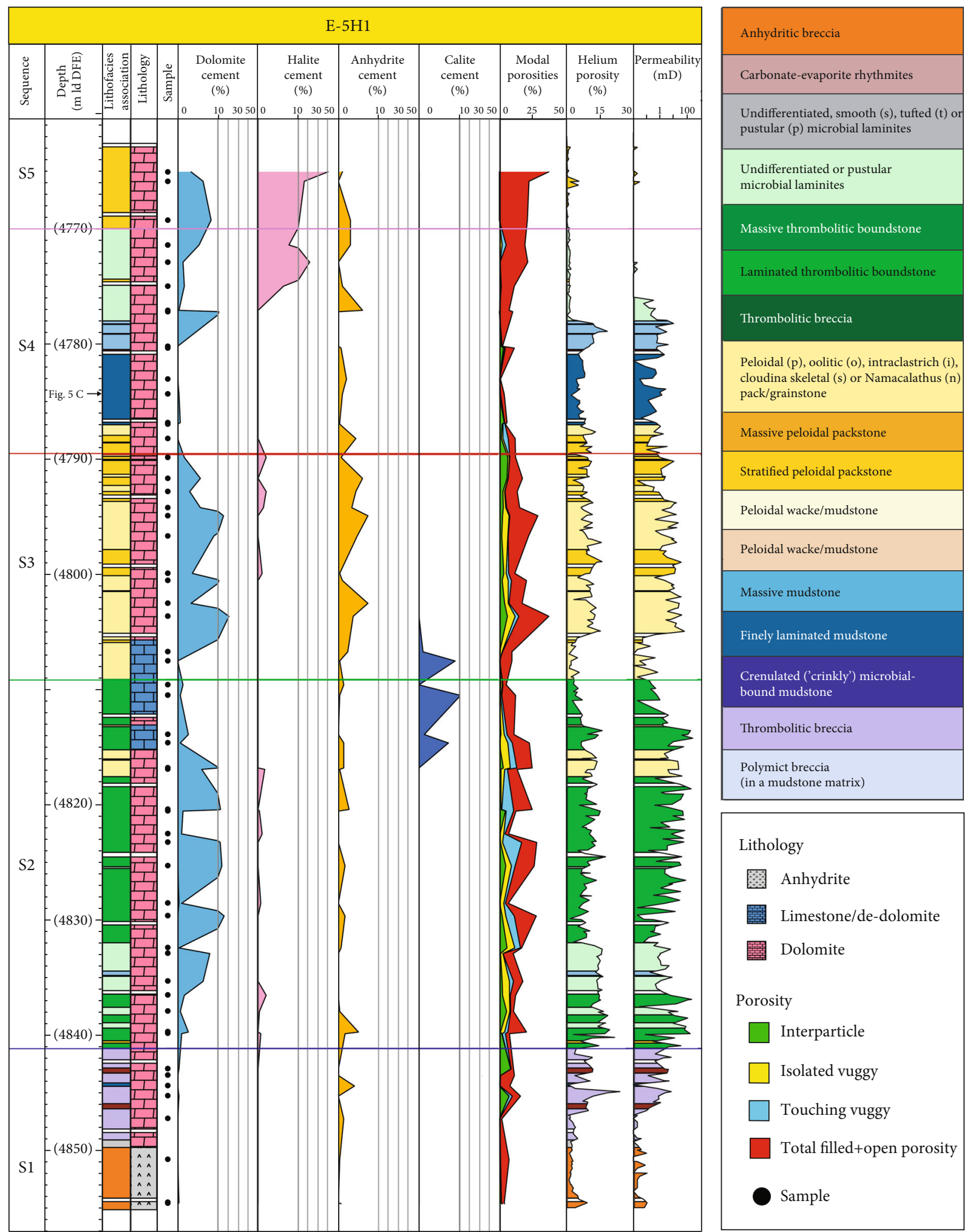

Figure 6: Vertical distribution trends of modal cement phases, porosities, and permeability in the well E-5H1. Intense dolomite, halite, and anhydrite cementation of the pack-/grainstone and thrombolites facies in the uppermost sequence 5 leads to a nearly complete loss of porosity, although both facies had initially high porosities and permeability. Calcite cementation occurs only locally but leads to a reduction of permeability and porosity, especially in thrombolite and mudstone facies. The positions of sample presented in Figure 5(c) are indicated by an arrow. 

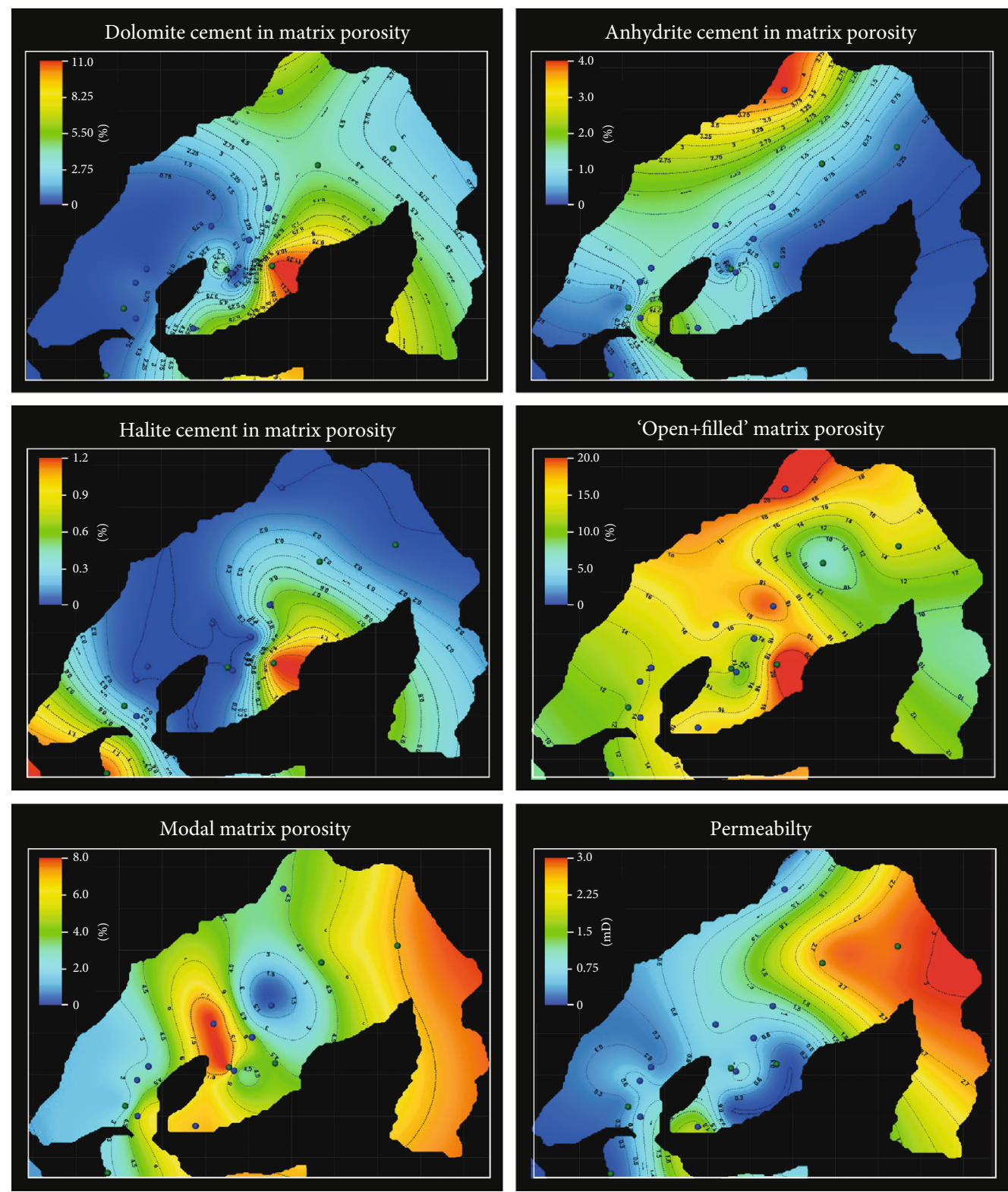

FIGURE 7:2D interpolation diagenesis maps for dolomite, anhydrite, and halite, different types of porosity ("open+filled" matrix porosity and modal matrix porosity) and permeability in the entire $\mathrm{A} 2 \mathrm{C}$ carbonate stringer. The "open+filled" matrix porosity map displays the total open and cemented porosity outside fractures. It is as an approximation of the distribution of open primary and early secondary porosity shortly after the replacement of limestone by dolomite, since late porosity creating processes seem to be unimportant.

a paragenetic sequence (Figures 5 and 9). Fluid inclusion assemblages showing only all-liquid fluid inclusions devoid of inclusions containing vapor bubbles were interpreted to have formed below $50^{\circ} \mathrm{C}$ [31], indicating a near-surface origin. This type of fluid inclusion assemblage was exclusively found in some halite cements. The most important paragenetic markers used bedding parallel stylolites (Figure 5(g)), which define the onset of intermediate burial diagenesis [35]. Stylolites forming a high angle with respect to bedding are tectonically induced (Biehl et al. 2016) and are interpreted to have formed during salt tectonic deformation [8]. The deep burial realm denotes the broad field of diagenetic alterations beginning with hydrocarbon generation [35] and is indicated by inclusion of angular fragments of solid bitumen (Figure 5(h)) or oil droplets (Figure 5(f)).

Reservoir bitumen was observed in different textural positions: as pore-filling phase in intercrystalline and vuggy pores, as lining around anhydrite nodules and anhydrite/calcite-filled pores, and as fracture-filling phase in microfractures. The reflectance measurements have shown that the position has only a negligible impact on the bitumen reflectance.

Average maximum burial temperatures of $128+12^{\circ} \mathrm{C}$ (1s, $n=30$ ) were calculated from the bitumen reflectance, which fit well with basin modeling results for the study area (Table 1; Figure 10; [34]). Most samples show maximum 

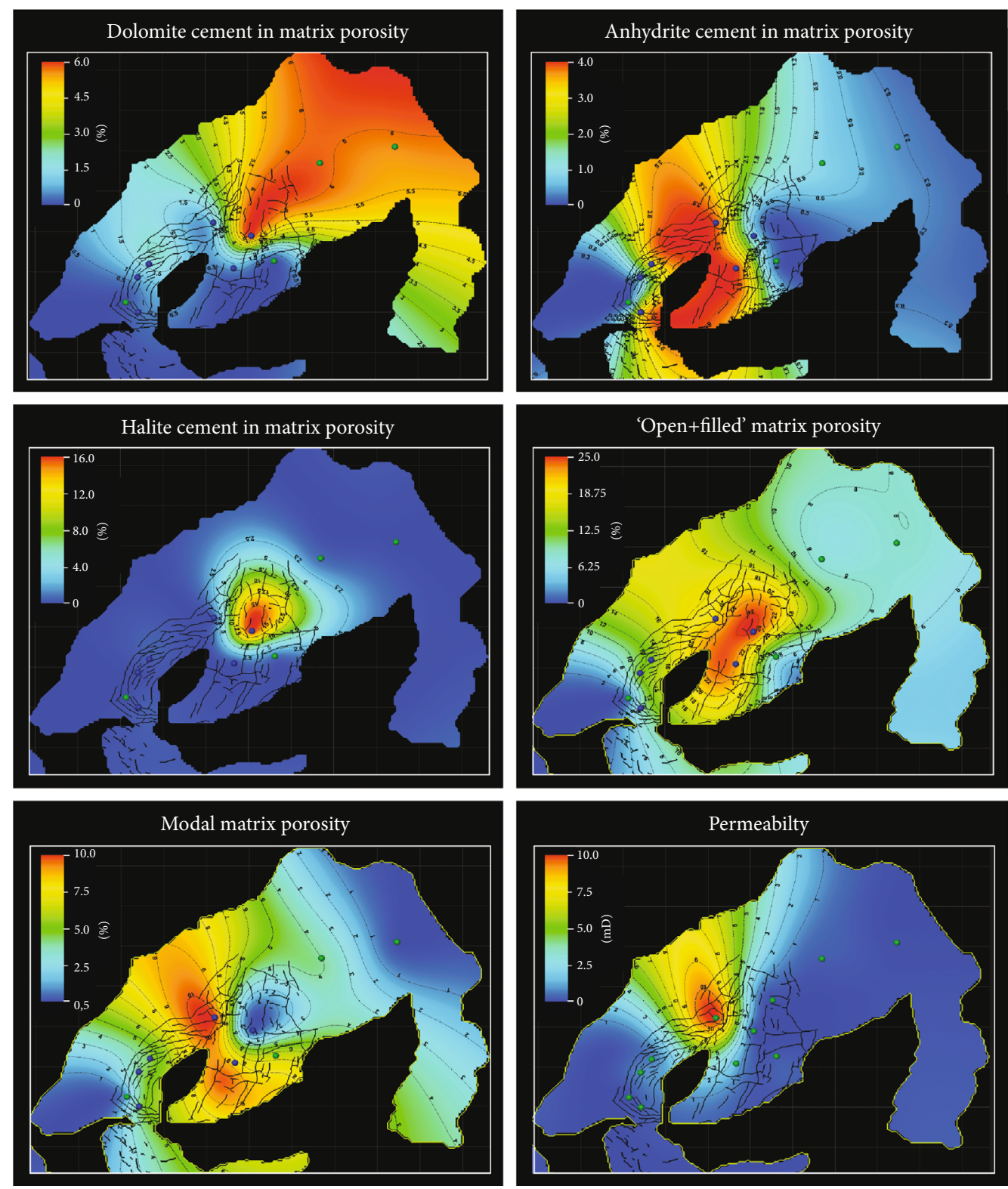

Figure 8: 2D interpolation diagenesis maps for sequence 5.

burial temperatures only slightly higher than the present-day borehole temperature (BHT, Scholten 2009, pers. comm.), with the exception of few wells that show average calculated maximum burial temperatures exceeding the BHTs by $10-35^{\circ} \mathrm{C}$ (Table 1, Figure 10).

Carbon and oxygen isotopes of 128 carbonate samples were measured (Figure 11). For dolomite, the mean $\delta^{13} \mathrm{C}$ is $2.1+1.0 \% \mathrm{~V}$-PDB and the mean $\delta^{18} \mathrm{O}$ is $-2.4+1.0 \%$ o $\mathrm{V}$-PDB ( $1 \mathrm{~s} ; n=124)$. The carbon isotope values for dolomite cements and matrix largely overlap, with a tendency towards lighter $\delta^{13} \mathrm{C}$ values in pore-filling $(1.8+0.7 \%$ o $\mathrm{V}-\mathrm{PDB}, \quad n=7)$ and heavier values in fracture-filling cements $(2.7+0.3 \%$ o $-\mathrm{PDB}, n=3)$ compared to replacive dolomite $(2.3+0.6 \%$ V $-\mathrm{PDB}, n=109)$. The bulk of the $\delta^{13} \mathrm{C}$ values is positive, with the notable exception of four isotope values from well E-4H1 (Figure 11). The oxygen isotope values for dolomite cements and matrix largely overlap, with a tendency towards lighter $\delta^{18} \mathrm{O}$ values in pore-filling $(-2.8+0.5 \%$ V-PDB, $n=7)$ and in fracture-filling cements $(-3.0+0.3 \%$ o $-\mathrm{PDB}, n=3)$ compared to replacive dolomite $(-2.5+0.8 \%$ V-PDB, $n=109)$. All except one sample from well $\mathrm{G}-4 \mathrm{H} 1$ show negative $\delta^{18} \mathrm{O}$ values ranging from -0.2 to $-4.1 \%$ V $-\mathrm{PDB}$ (Figure 11). For calcite, the mean $\delta^{13} \mathrm{C}$ is $1.4+0.6 \%$ V $-\mathrm{PDB}$ and the mean $\delta^{18} \mathrm{O}$ is $-4.6+2.2 \%$ $\mathrm{V}-\mathrm{PDB}(1 \mathrm{~s} ; n=26)$, with a total range from 0.5 to $2.5 \%$ $\mathrm{V}-\mathrm{PDB}$ and -1.5 to $-10.5 \% \mathrm{~V}-\mathrm{PDB}$, respectively.

Sulfur isotopes of 57 anhydrite samples were measured. Different types of cements (pores, fractures, and tension gashes) and replacive/displacive phases (laths, rosettes, or nodules) were sampled. The mean $\delta^{34} \mathrm{~S}$ of all samples is $40.0+2.7 \%$ V-CDT $(1 \mathrm{~s}, n=57)$ with a large range from 30.7 to $42.9 \%$ V-CDT (Figure 12 ). Pore-filling anhydrite 


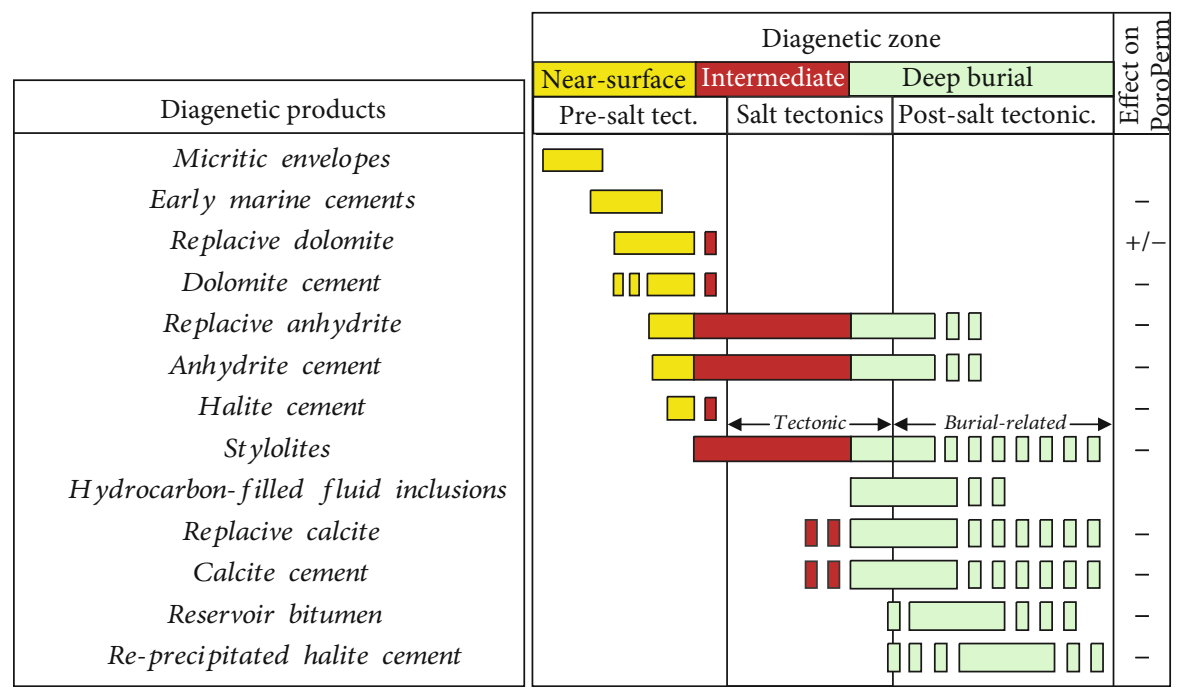

FIGURE 9: Paragenetic sequence for the studied A2C reservoir. Effects on porosity and permeability are indicated on the right. Near-surface diagenesis predates salt tectonic deformation and is characterized by products of the early marine diagenesis and reflux-related processes. Burial-related stylolites indicate the intermediate burial diagenesis realm. The presence of hydrocarbons and reservoir bitumen defines the deep burial realm that at least partially postdates the salt tectonic phase.

cement shows a mean $\delta^{34} \mathrm{~S}$ of $39.9+1.0 \% \mathrm{~V}-\mathrm{CDT}(1 \mathrm{~s}, n=8)$, while anhydrite cement in tension gashes shows a mean $\delta^{34} \mathrm{~S}$ of $39.5 \% \mathrm{~V}$-CDT $(n=3)$ with a narrow range from 39.3 to $39.6 \%$ V-CDT. Fracture-filling anhydrite cements display a mean $\delta^{34} \mathrm{~S}$ of $38.6+3.2 \%$ V-CDT $(1 \mathrm{~s}, n=11)$ with the overall highest range from 32.5 to $42.4 \%$ V-CDT. Replacive/displacive anhydrites display a mean $\delta^{34} \mathrm{~S}$ of $40.4+2.7 \%$ o V-CDT $(1 \mathrm{~s}, n=34)$ with a broad range from 30.7 to $42.9 \%$ V-CDT. A single primary, laminated anhydrite sample in comparison is characterized by a $\delta^{34} \mathrm{~S}$ of $42.3 \%$ o $-C D T$.

\section{Discussion}

5.1. Diagenetic Processes and Fluid Composition in the NearSurface Diagenetic Realm. Carbonate facies of the Ara Group are thought to be microbially influenced, except for some packstones to grainstones [15, 26]. Mettraux et al. [36, 37] describe microbial fossils from calcitic and dolomitic Ara Group carbonates exposed in a salt dome in central Oman and argue that the fine crystalline matrix dolomite is of primary, microbial origin. The dolomitic matrix in the studied reservoirs is also very fine crystalline and preserves high microporosity [26].

In most of the studied reservoirs, dolomite is the dominant lithology, whereas limestone is nearly exclusively present in thrombolitic facies. The fact that clastic-textured grainstone-packstones are almost invariably dolomitized [15] indicates that dolomitization is not restricted to microbial facies. However, microbially mediated dolomite precipitation might have occurred in the microbial-influenced facies [26] and could have acted as seeds for later reflux-related dolomitization [38].

The earliest clearly diagenetic products are micritic envelopes around allochems often coated by isopachous rims of bladed cement (Figure 5(a)). Micritized allochems most likely were formed by boring algae and/or fungi (Figure 5(a); [39]), in normal marine seawater during early marine diagenesis. Calcite crystals filling growth framework porosity in thrombolites often show a fan-like shape and are interpreted as early marine cement or a replacement of possibly aragonitic, botryoidal cement. Similar early marine cementation has been described by Mettraux et al. [36, 37] for time-equivalent carbonates exposed in a salt dome in central Oman.

The top of sequence 2 and associated breccias were interpreted as subaerial exposure surface (Figure 2, [15]). Diagenetic textures which could be unequivocally attributed to meteoric diagenesis have not been identified in thin-section or isotope data, but vuggy pores interpreted as meteoric dissolution have been reported from other wells within the Harweel cluster [15].

Dolomite, anhydrite, and halite cements are important diagenetic products which are interpreted to be of reflux origin ([5]; Figures 6-8 and 13). One-phase aqueous fluid inclusions in halite cements devoid of oil or bitumen inclusions support a formation in the near-surface realm at temperature below $\sim 50^{\circ} \mathrm{C}[31]$. All reflux-related phases can very precisely be linked to the burial graph since reflux effectively ends when the stringers are sealed by an overlying rock salt layer that typically becomes impermeable if its thickness exceeds $\sim 30 \mathrm{~m}$ (Figure 1(b); [5, 40]). Reflux dolomitization by $\mathrm{Mg}^{2+}$-rich brines is often assumed for evaporite-associated carbonate platforms [41-44]. During reflux dolomitization, the precursor limestone is first replaced by dolomite followed by precipitation of dolomite cements, a process known as overdolomitization [45]. Both types of dolomite, replacive dolomite and dolomite cements that clearly postdates the replacive dolomites (Figure 5(b)), were observed within the studied wells. Matrix dolomite shows generally dull luminescence in contrast to the bright luminescent dolomite cements (Figure 5(b)). Ongoing evaporation leads to increasing 
TABLE 1: Bitumen reflectance measurements.

\begin{tabular}{|c|c|c|c|c|c|c|}
\hline Well & Sample & $\begin{array}{c}\text { Depth } \\
\text { (m dd DFE) }\end{array}$ & Sequence & Bitumen reflectance (BR) & $\begin{array}{l}\text { Vitrinite reflectance } \\
\text { (after Jacob, 1989) }\end{array}$ & $T_{\text {burial }}\left({ }^{\circ} \mathrm{C}\right)$ \\
\hline $\mathrm{E}-4 \mathrm{H} 1$ & $\mathrm{E} 4-4$ & 4766.47 & S5 & 0.83 & 0.91 & 128 \\
\hline $\mathrm{E}-4 \mathrm{H} 1$ & $\mathrm{E} 4-6$ & 4772.08 & S5 & 1.10 & 1.08 & 142 \\
\hline $\mathrm{E}-4 \mathrm{H} 1$ & $\mathrm{E} 4-13$ & 4787.58 & S4 & 1.03 & 1.03 & 138 \\
\hline $\mathrm{E}-5 \mathrm{H} 1$ & E5-1 & 4760.46 & S5 & 1.08 & 1.06 & 141 \\
\hline $\mathrm{E}-5 \mathrm{H} 1$ & E5-12 & 4792.06 & S3 & 0.88 & 0.94 & 131 \\
\hline $\mathrm{E}-9 \mathrm{H} 2$ & E9-14 & 4737.52 & S4 & 0.70 & 0.83 & 121 \\
\hline $\mathrm{E}-9 \mathrm{H} 2$ & E9-17 & 4743.18 & S4 & 0.68 & 0.82 & 119 \\
\hline $\mathrm{E}-9 \mathrm{H} 2$ & E9-22 & 4747.52 & S4 & 1.08 & 1.06 & 141 \\
\hline E-9H2 & E9-45 & 4784.27 & S2 & 0.98 & 1.00 & 136 \\
\hline E-11H3 & E11-2 & 4632.56 & Floater & 0.73 & 0.85 & 122 \\
\hline E-11H3 & E11-10 & 4669.07 & S3 & 0.63 & 0.79 & 116 \\
\hline G-2H1 & G2-10 & 4915.00 & S5 & 0.80 & 0.89 & 126 \\
\hline G-2H1 & G2-23 & 4992.19 & S4 & 1.28 & 1.19 & 149 \\
\hline G-2H1 & G2-35 & 4980.34 & S2 & 1.13 & 1.10 & 143 \\
\hline G-3H2 & G3-4 & 4941.49 & S4 & 0.68 & 0.82 & 119 \\
\hline G-3H2 & G3-4 & 4941.49 & S4 & 0.63 & 0.79 & 116 \\
\hline G-3H2 & G3-4 & 4941.49 & S4 & 1.18 & 1.13 & 145 \\
\hline G-3H2 & G3-4 & 4941.49 & S4 & 1.13 & 1.10 & 143 \\
\hline G-3H2 & G3-39 & 5015.17 & S1 & 0.48 & 0.69 & 106 \\
\hline G-3H2 & G3-39 & 5015.17 & S1 & 0.78 & 0.88 & 125 \\
\hline $\mathrm{G}-4 \mathrm{H} 1$ & G4-5 & 4950.90 & S4 & 0.42 & 0.66 & 102 \\
\hline G-4H1 & G4-5 & 4950.90 & S4 & 1.30 & 1.20 & 150 \\
\hline G-4H1 & G4-10 & 4963.54 & S4 & 0.58 & 0.76 & 113 \\
\hline $\mathrm{G}-4 \mathrm{H} 1$ & G4-11 & 4965.94 & S4 & 0.68 & 0.82 & 119 \\
\hline G-8H1 & G8-2 & 4951.33 & S5 & 0.83 & 0.91 & 128 \\
\hline G-8H1 & G8-21 & 4996.48 & S3 & 0.68 & 0.82 & 119 \\
\hline G-8H1 & G8-33 & 5026.45 & S2 & 0.63 & 0.79 & 116 \\
\hline $\mathrm{F}-1 \mathrm{H} 1$ & F1-11 & 5048.68 & S2 & 0.73 & 0.85 & 122 \\
\hline $\mathrm{F}-1 \mathrm{H} 1$ & F1-12 & 5050.63 & S2 & 0.83 & 0.91 & 128 \\
\hline $\mathrm{F}-1 \mathrm{H} 1$ & F1-19 & 5063.98 & S2 & 0.80 & 0.89 & 126 \\
\hline
\end{tabular}

salinity of the seawater and refluxing brines and hence, during further near-surface diagenesis, to an increased precipitation of evaporitic minerals within the remaining pore space [46]. An early phase of anhydrite cementation/replacement is indicated by compactional drapes around some anhydrite nodules (Figure 5(c)) indicating that these nodules have formed prior to the end of physical compaction. The sulfate source for the formation of diagenetic anhydrite can be constrained using sulfur isotope values. The measured sulfur isotope values of diagenetic anhydrite (Figure 12) largely overlap with the sulfur isotope values of sedimentary sulfates of the Ara Group that cluster between 38 and 44\%o V-CDT, with individual excursions down to $\sim 32 \mathrm{~V}-\mathrm{CDT}[17,47]$. This relatively high total range is attributed to local processes in the partly restricted basin $[17,47,48]$. Generally, the higher sulfur isotope values in the roof and floor anhydrites are thought to represent times of increased basin restriction [47]. Lower sulfur isotope values characterize periods of freshening, with partial oxidation of sulfides during times of initial basin flooding [47]. The similar $\delta^{34} \mathrm{~S}$ isotope values in sedimentary sulfates and diagenetic anhydrite phases suggest that the sulfate-rich fluids were sourced from the bounding anhydrite units, either during reflux or later gypsum to anhydrite transformation. The floor and roof anhydrites originally were deposited as gypsum [17]. Up to $40 \mathrm{vol} \%$ of structural bound water is expelled during recrystallization from gypsum to anhydrite, which likely takes place in burial depth of less than $250 \mathrm{~m}[49,50]$. The escaping water is oversaturated with respect to $\mathrm{CaSO}_{4}[51]$ and might have led to a second pulse of anhydrite cementation and replacement during shallow burial.

5.2. Spatial Distribution of Reflux-Related Cements. The degree of dolomite cementation is known to increase towards the entry point of refluxing brines [44]. The strongest dolomite cementation within the uppermost carbonate sequence was found in the north-eastern part of the carbonate platform where initially highly porous facies could have acted 

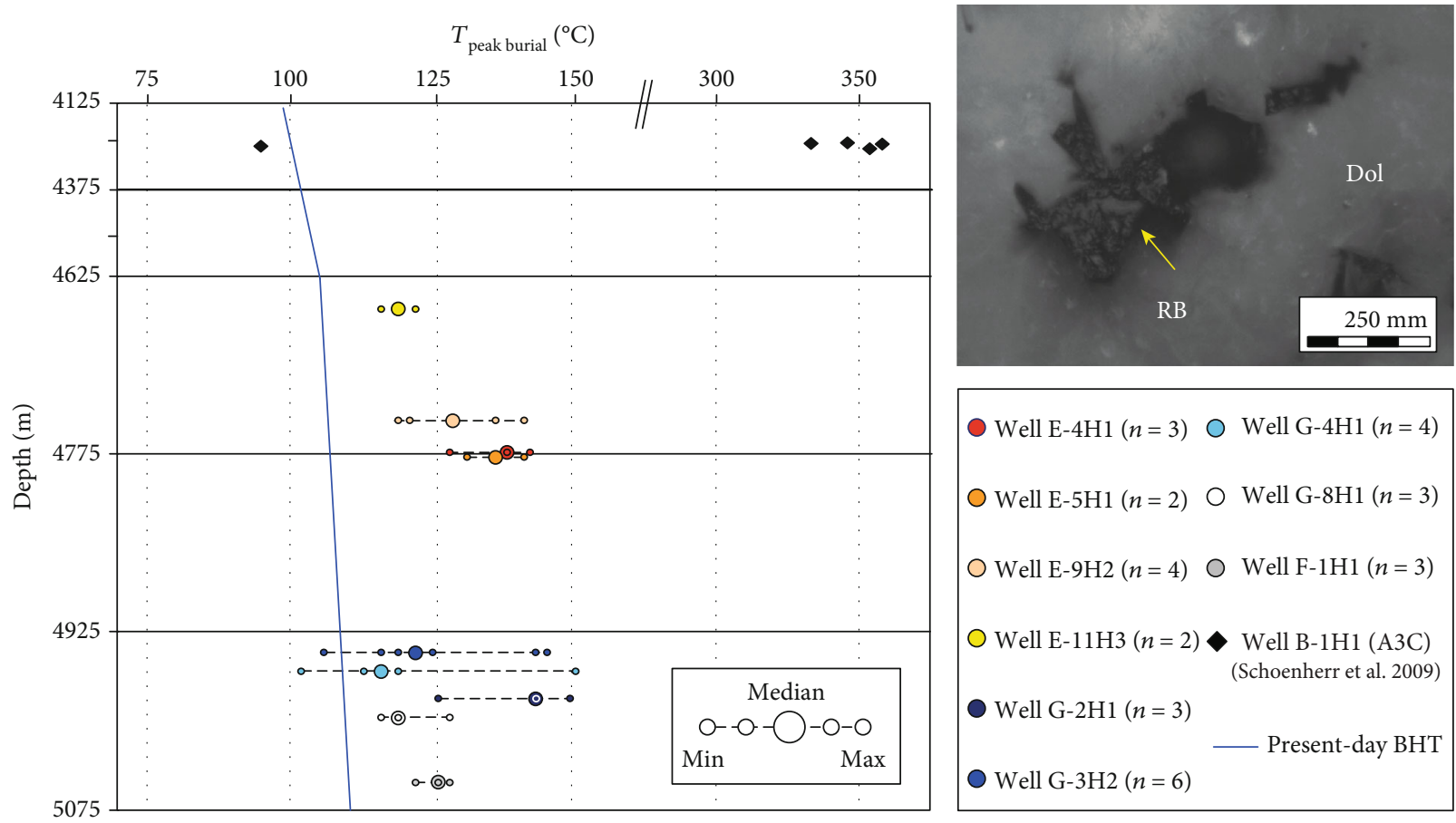

FIGURE 10: Maximum burial temperatures calculated from measured bitumen reflectance (BRr) plotted against present-day depth. A photograph of reservoir bitumen (RB) as pore-filling phase under reflected light is shown in the upper right corner. The error bars indicate the temperature ranges of all samples per well. The averaged maximum burial temperature of all wells is $128^{\circ} \mathrm{C}$. The calculated temperatures show no evidence for a hydrothermal event as described for the A3C interval within the well B-1H1 [60].

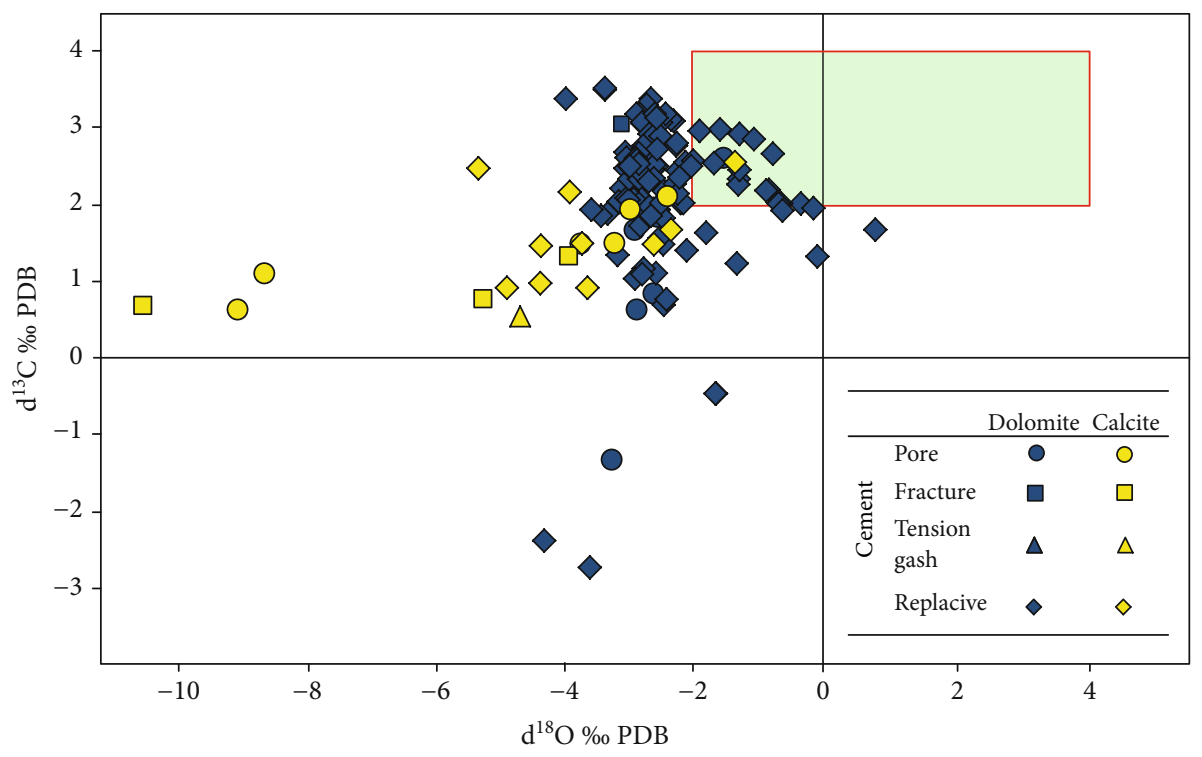

Figure 11: Oxygen and carbon isotope values of carbonates. Green square: assumed primary isotope ratios of the latest Neoproterozoic carbonates. Carbon isotopic composition is based on the latest Neoproterozoic carbonate samples [75]. Oxygen isotopic composition is based on Cenozoic carbonates [76] assuming that $\delta^{18} \mathrm{O}$ values of Neoproterozoic seawater were similar to the Cenozoic ocean [57, 76]. Dolomite samples from modern sabkha environments range from 0 to 4 permil [77].

as a conduit for brine reflux from the overlying anhydrite and halite beds (Figures 6 and 8 ). The pattern is shown exemplarily for one well where initially highly porous packstones and microbialites below the evaporites are nearly completely plugged by reflux-related cement phases, such as halite and to a lesser degree dolomite (Figure 6). The underlying low permeable mudstones are in contrast devoid of halite cements (Figure 6). The minor halite cementation below 


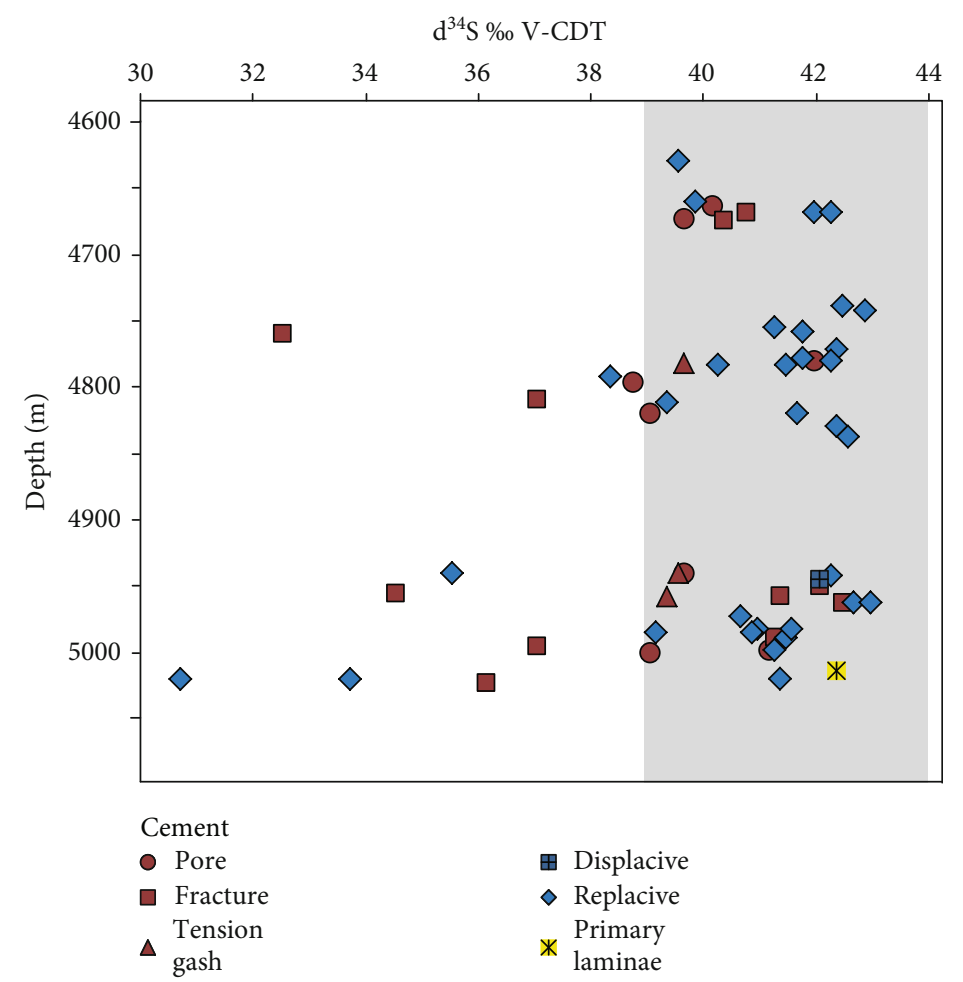

FIgURE 12: Sulfur isotope values. Grey rectangle indicates the typical sulfur isotope signal of sedimentary sulfate embedding the carbonate intervals within the Ara Group [17, 47].

might indicate that the mudstone layer might have acted as a vertical barrier that redirected the refluxing brines from a vertical flow into a more lateral flow along high permeable facies, which likely might have sheltered the underlying sequences from a reflux-related cementation from above.

Replacement of the precursor limestone by dolomite can be expressed by the formula [52]

$$
2 \mathrm{CaCO}_{3}+\mathrm{Mg}^{2+} \rightarrow \mathrm{CaMg}(\mathrm{CO} 3)_{2}+\mathrm{Ca}^{2+}
$$

Reactive transport models suggest that the released $\mathrm{Ca}^{2+}$ ions lead to an increased anhydrite cementation in facies basinward of the dolomitization front, whereas subsequent dolomite cementation close to the source of nearly halitesaturated brines will lead to anhydrite dissolution $[43,53]$, possibly by removal of $\mathrm{Ca}^{2+}$ from the pore water. These modeling results are broadly consistent with the observed spatial distribution of diagenetic phases (Figures 5 and 8). The spatial distribution patterns found in the uppermost sequence indicate that anhydrite cement predominantly reduces the porosity along a north-south trend below the Haima pod (Figure 8) whereas dolomite and halite cementation preferentially occurred in the north-eastern part of the carbonate platform close to the interpreted entry point of the refluxing brines. For the complete stringer, the spatial relation between different reflux-related cements seems to be more complex and difficult to predict (Figure 7). This is likely the result of multiple entry points for the refluxing brines in these basin-wide evaporites, which is in stark contrast to platforms where evaporites are limited to the restricted inner platform area.

5.3. Diagenetic Processes and Fluid Composition during Intermediate Burial. Sedimentation of thick evaporite units of the Ara Group led to a rapid burial of the carbonate platform during the Late Neoproterozoic and Early Cambrian. Bedding parallel stylolites are commonly thought to form in a minimum burial depth of around 500-1000 $\mathrm{m}$ in dolomite (Figure 12; $[54,55]$ ) and are therefore used as markers for the onset of intermediate burial diagenesis [35]. Cooccurrence of anhydrite and calcite cements in tension gashes associated with bedding parallel stylolites indicates that anhydrite cementation continued into the burial realm (Figure $5(\mathrm{~g})$ ). The close association of many calcite cements to stylolites also suggests a burial origin. Calcite cements occlude the intercrystalline pore space (Figure $5(\mathrm{~g})$ ) of the dolomite matrix and therefore contribute to porosity reduction (Figure 6). This reprecipitation of carbonate dissolved along stylolites as calcite cement seems to be a common process within carbonate reservoirs [56].

The burial origin of calcite cement is also supported by its oxygen and carbon isotope values, displaying a typical burial trend to depleted $\delta^{18} \mathrm{O}$ and slightly depleted $\delta^{13} \mathrm{C}$ values in calcite cements relative to the assumed primary isotopic signature of the latest Neoproterozoic carbonates (Figure 11). Recrystallization or precipitation under increasing temperatures during progressive burial shifts the $\delta^{18} \mathrm{O}$ ratio towards more negative values. Dolomite shows a similar but less pronounced shift in $\delta^{18} \mathrm{O}$, indicating recrystallization in the 


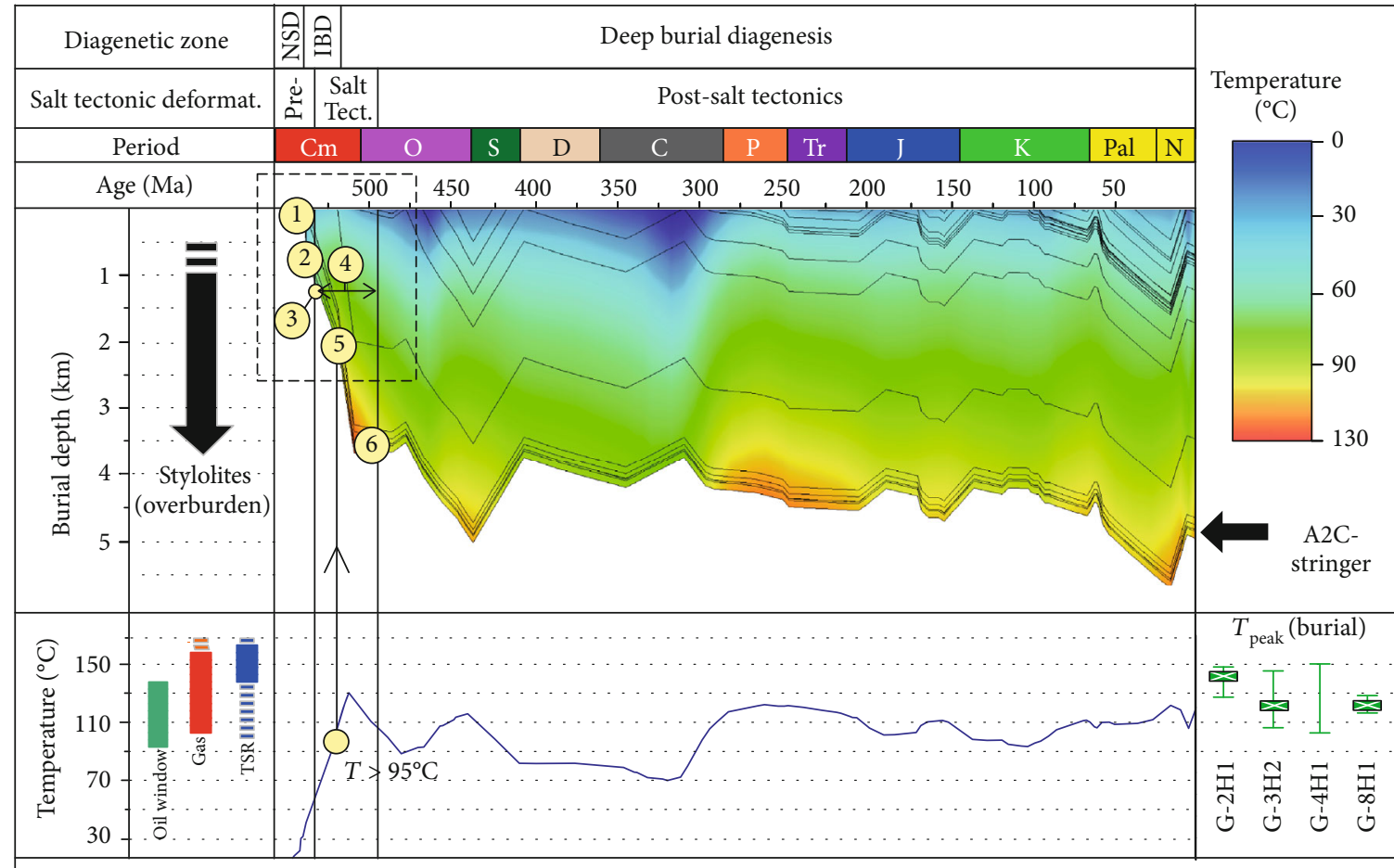

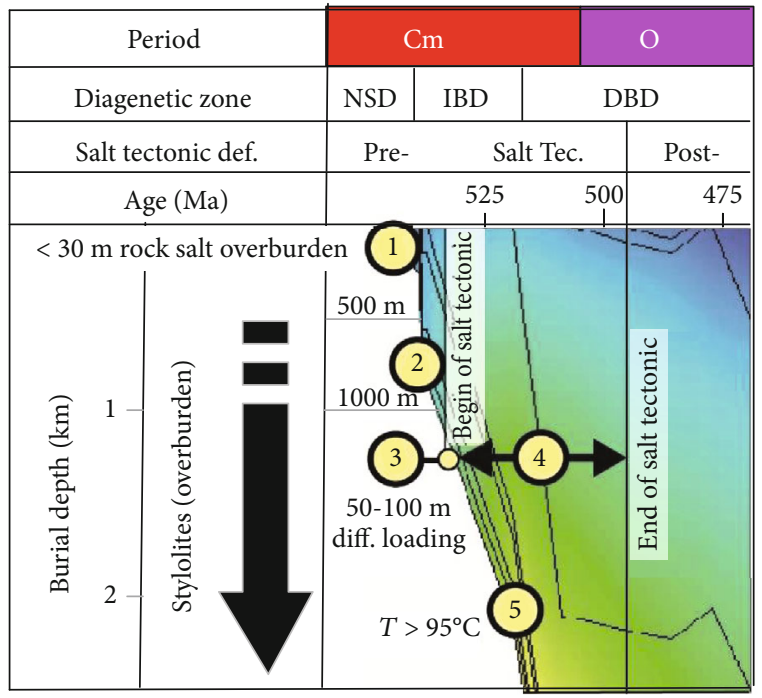

(1) Rock salt < $30 \mathrm{~m}$ :

1 near- surface diagenesis

2 500 - 1000 m overburden:

1st stylolites

30 - 100 m differential loading:

1st stringer breakage

Salt tectonic deformation:

4 tectonic stylolites

5) $T>95^{\circ} \mathrm{C}$ : 1 st hydrocarbons



FIGURE 13: Summary of diagenetic processes and burial graph for the A2C reservoir (modified from [34]). Numbers refer to important steps in the diagenetic history of the Ara carbonate stringer. Note that all important developments happened during the first $~ 50$ Ma of burial. NSD: near-surface diagenesis; IBD: intermediate burial diagenesis. Please note that maximum burial temperatures were just below the typical temperature threshold for thermochemical sulfate reduction (TSR). The relatively low maximum temperatures relative to the burial depth are at least partially due to the high thermal conductivity of halite.

presence of a geothermal gradient during burial [57]. Recrystallization and chemical compaction affected the calcite matrix to a larger extent compared to the dolomite matrix leading to a near complete porosity reduction in limestone due to the formation of an anhedral crystal mosaic [26]. This is supported by clumped isotope measurements for the studied stringer indicating a mean recrystallization temperature of $\sim 90^{\circ} \mathrm{C}$, with somewhat higher temperatures for calcite than for dolomite for the complete Ara Group [57]. In accordance with Bergmann et al. [57], the relatively narrow range of measured oxygen isotopes for the $\mathrm{A} 2 \mathrm{C}$ in this study confirms that the recrystallization took place in a closed system, rockbuffered diagenetic environment with low water to rock ratios during burial. The limited shift in $\delta^{13} \mathrm{C}$ values in most calcite and dolomite samples implies the incorporation of organically derived $\mathrm{CO}_{2}$ from kerogen breakdown during 
burial. Subsequent deposition of continental siliciclastics on the mobile Ara Salt led to a rapid burial as well as to strong salt tectonic movements (Figures 3 and 13; [28]). Differential loading formed clastic pods and salt diapirs, which led to folding and fragmentation of the carbonate platforms into isolated stringers floating in the Ara Salt. Finite element models (FEM) indicate that only $50-100 \mathrm{~m}$ differential load is needed to form fractures within the stringers (Figure 13; [8]). Anhydrite-cemented veins formed predominantly around the minibasin in the center of the study area [34]. These veins often postdate bedding parallel stylolites but are cross-cut by vertical stylolites that are interpreted to have formed during salt tectonic folding of the stringer (Figure 13). These fractures therefore have most likely formed during intermediate burial before the end of halokinetic deformation (Figure 6) at $500 \mathrm{Ma}$ [28].

\subsection{Diagenetic Processes and Fluid Composition during Deep} Burial. The first significant hydrocarbon generation denotes the broad field of diagenetic alterations of the deep burial realm [35]. Understanding the timing of first oil charge hence is of importance to link the paragenetic sequence to the burial and temperature history. For the entire study area, the averaged maximum burial temperature is $128^{\circ} \mathrm{C}$, exceeding the present-day $\mathrm{BHT}$ at this depth by $20^{\circ} \mathrm{C}$. Assuming the present-day geothermal gradient of $19^{\circ} \mathrm{C} / \mathrm{km}$, the maximum burial depth was $\sim 1000 \mathrm{~m}$ higher than at present. However, a calculation based on the present-day geothermal gradient (Scholten 2009, pers. comm.) might overestimate the maximum burial depth, since the Cenozoic heat flow in the South Oman was exceptionally low [58]. The onset of first oil generation was determined using the classification of Pepper \& Corvi [59]. They determined for aquatic-marine carbonates/evaporites (equivalent with IFP-kerogen type $\left.\mathrm{II}^{\prime} \mathrm{S}^{\prime}\right)$ the lower limit $\left(95^{\circ} \mathrm{C}\right)$ and the upper limit $\left(135^{\circ} \mathrm{C}\right)$ of the oil window. Notice that the assumed kerogen-type of Pepper \& Corvi [59] conforms with the geochemical data of Schoenherr [60] and Grosjean et al. [27], who determined preferentially kerogen type II (oil) and also kerogen type III (gas). The temperature history of the study area indicates that the reservoir reached the oil window during the initial sedimentation of the Amin Group ( 520 Ma; Figure 13). Hence, the first oil was generated during halokinesis. Subsequently, the reservoirs remain in the temperature range close to the lower limit of the oil window. The volumetrically most important diagenetic phase that formed during deep burial is reservoir bitumen, which reduces the porosity in intercrystalline/particle and vuggy pores but locally also in fracture porosity and can be used as an important time marker in a paragenetic sequence (Figures 5(f) and 5(h)).

Reservoir bitumen can form through a range of processes including bacterial sulfate reduction [61], thermochemical sulfate reduction (TSR; [42, 61]), gas deasphalting [62], biodegradation [63], pressure and temperature reduction [64], in-reservoir oil mixing [65], or thermal alteration [62].

Grosjean [27] has shown that the biomarkers within the stringer oils show no evidence for biodegradation. Thermal cracking also seems to be of minor importance since Pepper \& Corvi [59] have shown that the threshold of thermal crack- ing within aquatic-marine carbonates/evaporites is $>155^{\circ} \mathrm{C}$. Neither the temperature history (Figure 13) nor the maximum burial temperatures calculated from bitumen reflectance measurements (Figure 10) point to temperatures $>155^{\circ} \mathrm{C}$. In-reservoir oil mixing seems to be an implausible process since a mixing of crude oils from multiple source rocks [65] can be excluded due to the sealing of the stringers by rock salt. A charge of gaseous components from other source rock is needed for gas deasphalting, which can also be excluded due to the reason mentioned before. Temperatures between 100 and $140^{\circ} \mathrm{C}$ are thought to be necessary for the generation of thermochemical sulfate reduction [61]. The maximum burial temperatures of around $125^{\circ}$, derived from bitumen reflectance data (Figure 7) for the Ara carbonates, are within this range. However, the shortage of samples with negative carbon isotope values (Figure 8), the lack of calcitized anhydrite nodules, and the scarcity of anhydrite molds indicate that no significant sulfate reduction took place in the studied reservoir during burial $[61,66]$. This is consistent with the finding from several other carbonateevaporite basins, where thermochemical sulfate reduction initiated at minimum temperatures above $125^{\circ} \mathrm{C}[42,66,67]$. The temperatures therefore remained below the threshold necessary for TSR in the South Oman Salt Basin despite a maximum burial of close to $6 \mathrm{~km}$. This can at least in part be attributed to the high thermal conductivity of salt, which leads to a relative cooling at and below the base of salt diapirs [68].

The most likely process leading to the formation of reservoir bitumen in our study area is a rapid pressure reduction. Taylor et al. [69] argue that gas-condensate accumulations in Ara reservoirs originate from former oil phases that were subjected to a rapid change from litho- to hydrostatic pressures. Kukla et al. [7] proposed that such a pressure deflation event would have affected oil-bearing carbonate stringers in the terminal salt tectonic phase, when the overpressured reservoirs came in contact to the siliciclastic minibasins (Figures 3 and 13). In addition, the burial graph of the $\mathrm{A} 2 \mathrm{C}$ reservoir indicates several uplift events in postsalt tectonic times most likely leading to further pressure and temperature drops ([70]; Figure 13). Therefore, it cannot be excluded that further reservoir bitumen was also formed in postsalt tectonic times. Evidence for external hydrothermal fluids with temperatures up to $380^{\circ}$ derived from deeper presalt strata, which entered the intrasalt carbonates during times of basement activity, as observed by Schoenherr et al. [5] for the $\mathrm{A} 3 \mathrm{C}$ interval, are not indicated by bitumen reflectance measurements measured within this study (Figure 7). Late diagenetic porosity formation that can be associated with hydrothermal processes in evaporate-associated carbonates $[42,71]$ is also absent from the studied reservoirs.

Based on the knowledge on the process and timing of reservoir bitumen formation, the paragenetic sequence can be better constrained. Calcite and anhydrite cementation started in the intermediate burial realm but continued in the deep burial realm during oil charge, as indicated by inclusions of liquid oil and bitumen within these cement phases. Round oil inclusions, angular fragments of reservoir bitumen, and reservoir-cemented dolomite fragments in many of the halite cements (Figure 5(h)) indicate that partial dissolution and 
reprecipitation of halite cement occurred in the deep burial realm. A similar phase of dissolution and reprecipitation of halite cement was already observed for the A1C of the Harweel area by Schoenherr et al. [5]. Similar extensive deep burial halite cementation was described from the Late Permian (Zechstein) salt basin of central Europe. The halite-saturated fluids in this case are thought to be derived from dewatering of the underlying salt deposits or alternatively the mobilization of fluids during halokinesis [72]. Conditions suitable for solid bitumen formation were reached only during the end of the salt tectonic phase (Figure 13). However, halite solubility also increases with temperature and pressure [68]. Late halite cementation in the deep burial realm therefore could be explained by partial dissolution of early halite cement due to temperature and pressure increase during the rapid burial and reprecipitation associated with the temperate and pressure drop during uplift events (Figure 13).

\section{Conclusions}

The studied Neoproterozoic Ara Formation carbonate reservoir shows a relatively "simple" diagenetic history, despite its age and salt tectonic deformation. Changes in fluid chemistry from normal marine seawater to halite-saturated, Mg-rich brines during near-surface diagenesis determined to a large extent the porosity development within the reservoir. This successive change in fluid chemistry is typical for many evaporite basins and the presented diagenetic sequence therefore will also by characteristic for other carbonate-evaporite associations worldwide. Porosity reduction by marine cementation is generally minor and restricted to pack-/grainstones. Reflux-related dolomitization led to the formation of porosity that was successively reduced by dolomite, anhydrite, and halite cements during continued reflux. Precipitation of dolomite cement reduces the concentration of $\mathrm{Ca}^{2+}$ in the pore water and therefore might have led to dissolution of sulfate phases close to the entry points of refluxing brines, an observation that is consistent with reactive transport models of reflux dolomitization. However, in classical reflux dolomitization models, the source of the refluxing brines commonly is the restricted platform interior and the extent of reflux cementation decreases away from this source. In the case of basin-wide evaporites covering the entire carbonate reservoirs, the source of refluxing brines is not restricted to the platform interior. In the study area, the distribution of these reflux-related cements is therefore patchy and difficult to predict but is concentrated along facies that acted as high-permeable fluid pathways. Cementation by refluxrelated cements considerably reduced the initial porosity in these originally highly porous facies. This interaction of facies and diagenetic effects locally led to porosity inversion and a lack of facies control on reservoir properties. Within tens of meters of burial, the reservoir was effectively closed for external fluids but likely received a pulse of anhydritesaturated water due to gypsum to anhydrite dewatering before the onset of stylolitization. Rapid sedimentation of siliciclastic sediment led to the formation of minibasins and breakage of stringers due to halokinetic movements. The main diagenetic events in the burial realm are calcite cemen- tation related to stylolites and solid bitumen formation. A rapid pressure drop from litho- to hydrostatic conditions during the final phase of halokinesis likely contributed to the generation of reservoir bitumen and further porosity reduction. Processes with the potential to contribute porosity, such as thermochemical sulfate reduction or hydrothermal alteration, were suggested for other parts of the South Oman Salt Basin but could not be confirmed for the studied reservoir. The reservoirs experienced its maximum burial temperature around $125^{\circ} \mathrm{C}$ close to the end of halokinesis in the Early Ordovician. Diagenetic processes important for the reservoir development took place in the first $\sim 50 \mathrm{Ma}$ after sedimentation, whereas later diagenetic events likely are restricted to stylolitization and local redistribution of evaporite cements. Overall, the strong diagenetic overprint of primary and early diagenetic porosity by reflux-related cements leads to a reduction of stratigraphic and facies control on porosity. 2D interpolation diagenesis maps help to quantify and visualize this interaction of primary facies and diagenetic control on petrophysical properties and can provide the first step in assessing reservoir heterogeneity on a field scale.

\section{Data Availability}

All data used to support the findings of this study are deposited in the open access "RWTH publications" repository under the permanent link https://publications.rwth-aachen .de/record/229058/files/229058.pdf.

\section{Disclosure}

Lars Reuning's present address is Institute for Geosciences, Kiel University, Kiel, Germany. Stephan Becker's present address is Geologischer Dienst Nordrhein-Westfalen, Krefeld, Germany.

\section{Conflicts of Interest}

The authors declare that there are no conflicts of interest regarding the publication of this paper.

\section{Acknowledgments}

The authors would like to thank the Ministry of Oil and Gas of the Sultanate of Oman and Petroleum Development Oman (PDO) for granting permission to publish the results of this study. Furthermore, we are grateful to PDO for funding this study, providing samples and data and the fruitful discussions during our stays in Oman. We acknowledge the constructive comments of reviewer Andrea Ceriani that considerably improved the manuscript. We thank Gideon Lopes Cardozo, Zuwena Al Rawahi, Xiomara Marquez, Irene Gomez-Perez, Suleiman Farquani, and Aly Brandenburg from Petroleum Development Oman in particular for supporting many aspects of this project. We further are indebted to Ray Archer from Geochemistry Associates Ltd. for discussion and providing bitumen reflectance data. Michael Ruf and Deborah M. Bliefnick from Badley Ashton are thanked for discussion. Uwe Wollenberg is acknowledged 
for assistance during cathodoluminescence work. Philipp Binger and Rolf Mildenberger are thanked for thin-section preparation. The authors are grateful to Prof. Dr. R. Littke for using the institute's equipment during reflectance measurements. Furthermore, the authors would like to thank Prof. Dr. H. Strauss for carrying out the sulfur isotope measurements. Schlumberger is thanked for providing "PETREL" and "PETROMOD" under an Academic User License Agreement. Many thanks are due to our student assistants M. Oettel, J. Morwinski, S. Lamonby, E. Krejci, and B. Biehl for their support during this study. This work was supported by Petroleum Development of Oman. The publication of this article was approved by Petroleum Development of Oman and the Ministry of Oil and Gas of the Sultanate of Oman.

\section{Supplementary Materials}

Supplementary 1. Table S1: oxygen and carbon isotope values of carbonates shown in Figure 11, including information on mineralogy, depth in core, lithofacies, and type of diagenetic phase.

Supplementary 2. Table S2: sulfur isotope values of sulfate shown in Figure 12, including information on mineralogy, depth in core, lithofacies, and type of diagenetic phase.

Supplementary 3. Table S3: point counting results from nine wells, including information on well number, depth in core, and sequence.

\section{References}

[1] F. Strozyk, L. Reuning, M. Scheck-Wenderoth, and D. C. Tanner, "The tectonic history of the Zechstein Basin in the Netherlands and Germany," in Permo-Triassic Salt Provinces of Europe, North Africa and the Atlantic Margins: Tectonics and Hydrocarbon Potential, J. I. Soto, J. Flinch, and G. Tari, Eds., Elsevier, Amsterdam, 2017.

[2] J. K. Warren, Evaporites: A Compendium, Springer Verlag, Berlin, Heidelberg, New York, 2016.

[3] H. A. Al-Siyabi, "Exploration history of the Ara intrasalt carbonate stringers in the South Oman Salt Basin," GeoArabia, vol. 10, no. 4, pp. 39-72, 2005.

[4] J. Schoenherr, J. L. Urai, P. A. Kukla et al., "Limits to the sealing capacity of rock salt: A case study of the infra-Cambrian Ara Salt from the South Oman salt basin," AAPG Bulletin, vol. 91, no. 11, pp. 1541-1557, 2007.

[5] J. Schoenherr, L. Reuning, P. A. Kukla et al., "Halite cementation and carbonate diagenesis of intra-salt reservoirs from the Late Neoproterozoic to Early Cambrian Ara Group (South Oman Salt Basin)," Sedimentology, vol. 56, no. 2, pp. 567-589, 2009.

[6] H. A. Koyi, "Modeling the influence of sinking anhydrite blocks on salt diapirs targeted for hazardous waste disposal," Geology, vol. 29, no. 5, pp. 387-390, 2001.

[7] P. A. Kukla, L. Reuning, S. Becker, J. L. Urai, and J. Schoenherr, "Distribution and mechanisms of overpressure generation and deflation in the late Neoproterozoic to early Cambrian South Oman Salt Basin," Geofluids, vol. 11, no. 4, 361 pages, 2011.
[8] S. Li, S. Abe, L. Reuning, S. Becker, J. L. Urai, and P. A. Kukla, "Numerical modelling of the displacement and deformation of embedded rock bodies during salt tectonics - a case study from the South Oman Salt Basin," in Salt Tectonics, Sediments and Prospectivity, G. I. Alsop, S. G. Archer, A. J. Hartley, N. T. Grant, and R. Hodgkinson, Eds., vol. 363, pp. 503-520, Geological Society Special Publication, London, 2012.

[9] F. Strozyk, "The internal structure of the Zechstein salt and related drilling risks in the northern Netherlands," in PermoTriassic Salt Provinces of Europe, North Africa and the Atlantic Margins: Tectonics and Hydrocarbon Potential, J. I. Soto, J. Flinch, and G. Tari, Eds., Elsevier, Amsterdam, 2017.

[10] F. Strozyk, L. Reuning, S. Back, and P. A. Kukla, "Giant pockmark formation from cretaceous hydrocarbon expulsion in the westernmost Lower Saxony Basin, Netherlands," in Mesozoic Resource Potential in the Southern Permian Basin, B. Kilhams, P. A. Kukla, S. Mazur, T. Mckie, H. F. Mijnlieff, and K. Ojik, Eds., vol. 469, no. 1pp. 519-536, GSL Special Publications, 2018.

[11] B. P. Williamson, K. Walters, T. W. Bates, R. C. Coy, and A. L. Milton, "The viscoelastic properties of multigrade oils and their effect on journal- bearing characteristics," Journal of Non-Newtonian Fluid Mechanics, vol. 73, no. 1-2, pp. 115-126, 1997.

[12] D. N. Clark, "The distribution of porosity in Zechstein carbonates," in Habitat of Palaeozoic gas in N.W. Europe, J. Brooks, J. C. Goff, and B. Hoorn, Eds., vol. 23, no. 1pp. 167-203, Geological Society of London Special Publication, London, 1986.

[13] T. R. Seaborne, “The influence of the Sabatayn Evaporites on the hydrocarbon prospectivity of the Eastern Shabwa Basin, Onshore Yemen," Marine and Petroleum Geology, vol. 13, no. 8, pp. 963-972, 1996.

[14] L. Reuning, J. Schoenherr, A. Heimann et al., "Constraints on the diagenesis, stratigraphy and internal dynamics of the surface-piercing salt domes in the Ghaba Salt Basin (Oman): a comparison to the Ara formation in the South Oman Salt Basin," GeoArabia, vol. 14, no. 3, pp. 83-120, 2009.

[15] J. P. Grotzinger and Z. Al-Rawahi, "Depositional facies and platform architecture of microbialite-dominated carbonate reservoirs, Ediacaran-Cambrian Ara Group, Sultante of Om," AAPG Bulletin, vol. 98, no. 8, pp. 1453-1494, 2014.

[16] B. W. Mattes and M. Conway-Morris, "Carbonate/evaporite deposition in the Late Precambrian-Early Cambrian Ara formation of Southern Oman," in The Geology and Tectonics of the Oman Region, R. AHF, M. P. Searle, and A. C. Ries, Eds., vol. 49, pp. 617-636, Geological Society of London Special Publication, 1990.

[17] S. Schröder, B. C. Schreiber, J. E. Amthor, and A. Matter, "Stratigraphy and environmental conditions of the terminal Neoproterozoic-Cambrian period in Oman: evidence from sulphur isotopes," Journal of the Geological Society of London, vol. 161, no. 3, pp. 489-499, 2004.

[18] P. A. Allen, "The Huqf Supergroup of Oman: basin development and context for Neoproterozoic glaciation," EarthScience Reviews, vol. 84, no. 3-4, pp. 139-185, 2007.

[19] P. Immerz, W. H. Oterdoom, and M. El-Tonbary, "The Huqf/Haima hydrocarbon system of Oman and the terminal phase of the Pan-African orogeny: evaporite deposition in a compressive setting," GeoArabia, vol. 5, pp. 113-114, 2000.

[20] J. E. Amthor, K. Ramseyer, T. Faulkner, and P. Lucas, "Stratigraphy and sedimentology of a chert reservoir at the Precambrian-Cambrian Boundary: the Al Shomou Silicilyte, 
South Oman Salt Basin," GeoArabia, vol. 10, no. 2, pp. 89-122, 2005.

[21] G. A. Forbes, H. S. M. Jansen, and J. Schreurs, Lexicon of Oman subsurface stratigraphy: reference guide to the stratigraphy of Oman's hydrocarbon basins, GeoArabia Special Publication, Bahrain, 2010.

[22] J. E. Amthor, J. P. Grotzinger, S. Schröder et al., "Extinction of Cloudina and Namacalathus at the Precambrian-Cambrian boundary in Oman," Geology, vol. 31, no. 5, pp. 431-434, 2003.

[23] S. A. Bowring, J. P. Grotzinger, D. J. Condon, J. Ramezani, M. J. Newall, and P. A. Allen, "Geochronologic constraints on the chronostratigraphic framework of the Neoproterozoic Huqf Supergroup, Sultanate of Oman," American Journal of Science, vol. 307, no. 10, pp. 1097-1145, 2007.

[24] S. Schröder, B. C. Schreiber, J. E. Amthor, and A. Matter, “A depositional model for the terminal Neoproterozoic-Early Cambrian Ara Group evaporites in south Oman," Sedimentology, vol. 50, no. 5, pp. 879-898, 2003.

[25] S. Schröder, J. P. Grotzinger, J. E. Amthor, and A. Matter, "Carbonate deposition and hydrocarbon reservoir development at the Precambrian- Cambrian boundary: The Ara Group in South Oman," Sedimentary Geology, vol. 180, no. 1-2, pp. 1-28, 2005.

[26] J. Smodej, L. Reuning, S. Becker, and P. A. Kukla, "Micro- and nano-pores in intrasalt, microbialite-dominated carbonate reservoirs, Ara Group, South-Oman Salt Basin," Marine and Petroleum Geology, vol. 104, pp. 389-403, 2019.

[27] E. Grosjean, G. D. Love, C. Stalvies, D. A. Fike, and R. E. Summons, "Origin of petroleum in the NeoproterozoicCambrian South Oman Salt Basin," Organic Geochemistry, vol. 40, no. 1, pp. 87-110, 2009.

[28] B. Al-Barwani and K. R. McClay, "Salt tectonics in the Thumrait area, in the southern part of the South Oman Basin: implications for mini-basin evolution," GeoArabia, vol. 13, pp. 77-108, 2008.

[29] L. v. d. Plas and A. C. Tobi, "A chart for judging the reliability of point counting results," American Journal Science, vol. 263, no. 1, pp. 87-90, 1965.

[30] F. H. Nader, E. de Boever, M. Gasparrini et al., "Quantification of diagenesis impact on the reservoir properties of the Jurassic Arab D and C members (Offshore, U.A.E.)," Geofluids, vol. 13, no. 2, 220 pages, 2013.

[31] R. H. Goldstein and T. J. Reynolds, "Systematics of fluid inclusions in diagenetic minerals," Society for Sedimentary Geology Short Course, vol. 31, p. 199, 1994.

[32] H. Jacob, "Classification, structure, genesis and practical importance of natural solid oil bitumen ("migrabitumen")," International Journal of Coal Geology, vol. 11, no. 1, pp. 65-79, 1989.

[33] C. E. Barker and M. J. Pawlewicz, "Calculation of vitrinite reflectance from thermal histories and peak temperatures," ACS Symposium Series, vol. 570, pp. 216-229, 1994.

[34] S. Becker, "Reservoir quality in the A2C-stringer interval of the late neoproterozoic Ara-Group of the South Oman Salt Basin: diagenetic relationships in space and time," Ph.D. thesis, RWTH Aachen University, Aachen, 2013.

[35] H. G. Machel, "Investigations of burial diagenesis in carbonate hydrocarbon reservoir rocks," Geoscience Canada, vol. 32, no. 3, pp. 103-128, 2005.

[36] M. Mettraux, P. Homewood, S. Al Balushi, M. M. Erthal, and N. S. Matsuda, "Neoproterozoic microbialites in outcrops of the Qarn Alam salt dome, central Oman," GeoArabia, vol. 19, no. 3, pp. 17-76, 2014.

[37] M. Mettraux, P. Homewood, C. Dos Anjos, M. M. Erthal, and S. Al Balushi, "Microbial communities and their primary to early diagenetic mineral phases: the record from Neoproterozoic microbialites of Qarn Alam, Oman," in From Source to Seep: Geochemical Applications in Hydrocarbon Systems: Geological Society of London, M. Lawson, M. J. Formolo, and J. M. Eiler, Eds., vol. 418, pp. 123-154, Geological Society, London, Special Publications, 2015.

[38] N. Rameil, "Early diagenetic dolomitization and dedolomitization of Late Jurassic and earliest Cretaceous platform carbonates: a case study from the Jura Mountains (NW Switzerland, E France)," Sedimentary Geology, vol. 212, no. 1-4, pp. 70-85, 2008.

[39] R. G. C. Bathurst, "Boring algae, micrite envelopes and lithification of molluscan biosparites," Geological Journal, vol. 5, no. 1, pp. 15-32, 1966.

[40] E. Casas and T. K. Lowenstein, "Diagenesis or saline pan halite: comparison of petrographic features of modern, Quarternary and Permian halites," Journal of Sedimentary Petrology, vol. 59, no. 5, pp. 724-739, 1989.

[41] J. E. Adam and M. L. Rhodes, "Dolomitization by seepage refluxion," The American Association of Petroleum Geologists Bulletin, vol. 44, pp. 1912-1920, 1960.

[42] B. C. Biehl, L. Reuning, J. Schoenherr, V. Lüders, and P. A. Kulka, "Impacts of hydrothermal dolomitization and thermochemical sulfate reduction on secondary porosity creation in deeply buried carbonates: a case study from the Lower Saxony Basin, northwest Germany," AAPG Bulletin, vol. 100, no. 04, pp. 597-621, 2016.

[43] G. D. Jones and Y. Xiao, "Dolomitization, anhydrite cementation, and porosity evolution in a reflux system: insights from reactive transport models," The American Association of Petroleum Geologists Bulletin, vol. 89, no. 5, pp. 577-601, 2005.

[44] A. H. Saller and N. Henderson, "Distribution of porosity and permeability in platform dolomites; insights from the Permian of West Texas," The American Association of Petroleum Geologists Bulletin, vol. 82, no. 8, pp. 1528-1550, 1998.

[45] F. Lucia and R. Major, "Porosity evolution through hypersaline reflux dolomitization," in Dolomites: A Volume in Honor of Dolomieu, B. Purser, M. Tucker, and D. Zenger, Eds., vol. 21, pp. 325-341, International Association of Sedimentologists Special Publication, 1994.

[46] A. C. Kendall, "Compaction in halite-cemented carbonates the Dawson Bay Formation (Middle Devonian) of Saskatchewan, Canada," Sedimentology, vol. 47, no. 1, pp. 151-171, 2000.

[47] D. A. Fike and J. P. Grotzinger, “A $\delta 34 S S O 4$ approach to reconstructing biogenic pyrite burial in carbonate-evaporite basins: an example from the Ara Group, Sultanate of Oman," Geology, vol. 38, no. 4, pp. 371-374, 2010.

[48] D. A. Fike and J. P. Grotzinger, "A paired sulfate-pyrite $\delta^{34} \mathrm{~S}$ approach to understanding the evolution of the EdiacaranCambrian sulfur cycle," Geochimica et Cosmochimica Acta, vol. 72, no. 11, pp. 2636-2648, 2008.

[49] M. Hallenberger, L. Reuning, and J. Schoenherr, "Dedolomitization potential of fluids from gypsum-to-anhydrite conversion: mass balance constraints from the Late Permian Zechstein-2-carbonates in NW Germany," Geofluids, vol. 2018, 9 pages, 2018. 
[50] J. Schoenherr, L. Reuning, M. Hallenberger et al., "Dedolomitization: review and case study of uncommon mesogenetic formation conditions," Earth-Science Reviews, vol. 185, pp. 780-805, 2018.

[51] L. A. Hardie, "The gypsum-anhydrite equilibrium at one atmosphere pressure," American Mineralogist, vol. 5, no. 1-2, pp. 171-200, 1967.

[52] P. Weyl, "Porosity through dolomitization: conservation-of mass requirements," Journal of Sedimentary Petrology, vol. 30, no. 1, pp. 85-90, 1960.

[53] F. F. Whitaker, P. L. Smart, and G. D. Jones, "Dolomitization: from conceptual to numerical models," Geological Society, London, Special Publications, vol. 235, no. 1, pp. 99-139, 2004.

[54] H. V. Dunnington, Aspects of diagenesis and shape change in stylolitic limestone reservoirs, vol. 2, Abstract of 7th World Petroleum Congress, Mexico, 1967.

[55] E. Sellier, “Contribution à l'Étude Pétrologique Expérimentale de la Genèse des Stylolithes dans les Formations Calcaires du Bassin d'Aquitaine," Ph.D. thesis, University of Bordeaux, Bordeaux, 1979.

[56] M. Paganoni, A. Al Harthi, D. Morad et al., "Impact of stylolitization on diagenesis of a Lower Cretaceous carbonate reservoir from a giant oilfield, Abu Dhabi, United Arab Emirates," Sedimentary Geology, vol. 335, pp. 70-92, 2016.

[57] K. D. Bergmann, S. A. K. Al Balushi, T. J. Mackey, J. P. Grotzinger, and J. M. Eiler, "A 600-million-year carbonate clumped-isotope record from the Sultanate of Oman," Journal of Sedimentary Research, vol. 88, no. 8, pp. 960-979, 2018.

[58] J. J. M. Terken, N. L. Frewin, and S. L. Indrelid, "Petroleum systems of Oman: charge timing and risks," AAPG Bulletin, vol. 85, no. 10, pp. 1817-1845, 2001.

[59] A. S. Pepper and P. J. Corvi, "Simple kinetic models of petroleum formation. Part I: oil and gas generation from kerogen," Marine and Petroleum Geology, vol. 12, no. 3, pp. 291-319, 1995.

[60] J. Schoenherr, R. Littke, J. L. Urai, P. A. Kukla, and Z. Rawahi, "Polyphase thermal evolution in the Infra-Cambrian Ara Group (South Oman Salt Basin) as deduced by maturity of solid reservoir bitumen," Organic Geochemistry, vol. 38, no. 8, pp. 1293-1318, 2007.

[61] H. G. Machel, "Bacterial and thermochemical sulfate reduction in diagenetic settings - old and new insights," Sedimentary Geology, vol. 140, no. 1-2, pp. 143-175, 2001.

[62] A. Wilhelms and S. R. Larter, "Overview of the geochemistry of some tar mats from the North Sea and U.S.A.: implications for tar-mat origin," in The Geochemistry of Reservoirs, J. M. Cubitt and W. A. England, Eds., vol. 88, pp. 87-101, Geological Society of London Special Publication, 1995.

[63] J. Connan, "Biodegradation of crude oils in reservoirs," in Advances in Petroleum Geochemistry, J. Brooks and D. H. Welte, Eds., pp. 299-335, Academic Press Inc., London, 1984.

[64] N. E. Burke, R. E. Hobbs, and S. F. Kashou, "Measurement and modeling of asphaltene precipitation (includes associated paper 23831)," Journal of Petroleum Technology, vol. 42, no. 11, pp. 1440-1446, 1990.

[65] S. R. Larter, K. O. Bjørlykke, D. A. Karlsen et al., "Determination of petroleum accumulation histories: examples from the Ula field, Central Graben, Norwegian North Sea," in North Sea Oil and Gas Reservoirs-II, A. Buller, Ed., pp. 319-330, Springer, Dordrecht, 1990.
[66] R. H. Worden, P. C. Smalley, and N. H. Oxtoby, "Gas souring by thermochemical sulfate reduction at $140^{\circ} \mathrm{C}$," AAPG Bulletin, vol. 79, no. 6, pp. 854-863, 1995.

[67] E. Heydari, "The role of burial diagenesis in hydrocarbon destruction and $\mathrm{H} 2 \mathrm{~S}$ accumulation, Upper Jurassic Smackover Formation, Black Creek field, Mississippi," AAPG Bulletin, vol. 81 (1997), pp. 26-45, 1997.

[68] S. Y. Li, L. Reuning, G. Marquart, Y. Wang, and P. Y. Zhao, "Numerical model of halite precipitation in porous sedimentary rocks adjacent to salt diapirs," Journal of Geophysics and Engineering, vol. 14, no. 5, pp. 1160-1166, 2017.

[69] P. N. Taylor, A. Al-Harrasi, C. V. Eden, and M. Al-Ghammari, "Hydrocarbon charge and reservoir pressure history of the carbonate stringer play in South Oman - implications for pre-drill pore pressure risking," in GEO 2010, EAGE, 2010.

[70] W. Visser, "Burial and thermal history of Proterozoic source rocks in Oman," Precambrian Research, vol. 54, no. 1, pp. 15-36, 1991.

[71] B. C. Biehl, L. Reuning, J. Schoenherr, A. Lewin, M. Leupold, and P. A. Kukla, "Do CO2-charged fluids contribute to secondary porosity creation in deeply buried carbonates?," Marine and Petroleum Geology, vol. 76, pp. 176-186, 2016.

[72] D. N. Clark, "The diagenesis of Zechstein carbonate sediments," Contributions to Sedimentology, vol. 9, pp. 167-203, 1980.

[73] P. R. Sharland, R. Archer, D. M. Casey et al., "Arabian plate sequence stratigraphy," in GeoArabia Special Publication 2, Gulf Petrolink, Bahrain, 2001.

[74] M. Al-Husseini, "Middle East geological time scale," GeoArabia, vol. 15, no. 1, pp. 137-160, 2010.

[75] S. B. Jacobsen and A. J. Kaufman, "The Sr, C and O isotopic evolution of Neoproterozoic seawater," Chemical Geology, vol. 161, no. 1-3, pp. 37-57, 1999.

[76] L. P. Knauth and M. J. Kennedy, “The late Precambrian greening of the earth," Nature, vol. 460, no. 7256, pp. 728-732, 2009.

[77] J. K. Warren, "Dolomite: occurrence, evolution and economically important associations," Earth-Science Reviews, vol. 52, no. $1-3$, pp. 1-81, 2000. 

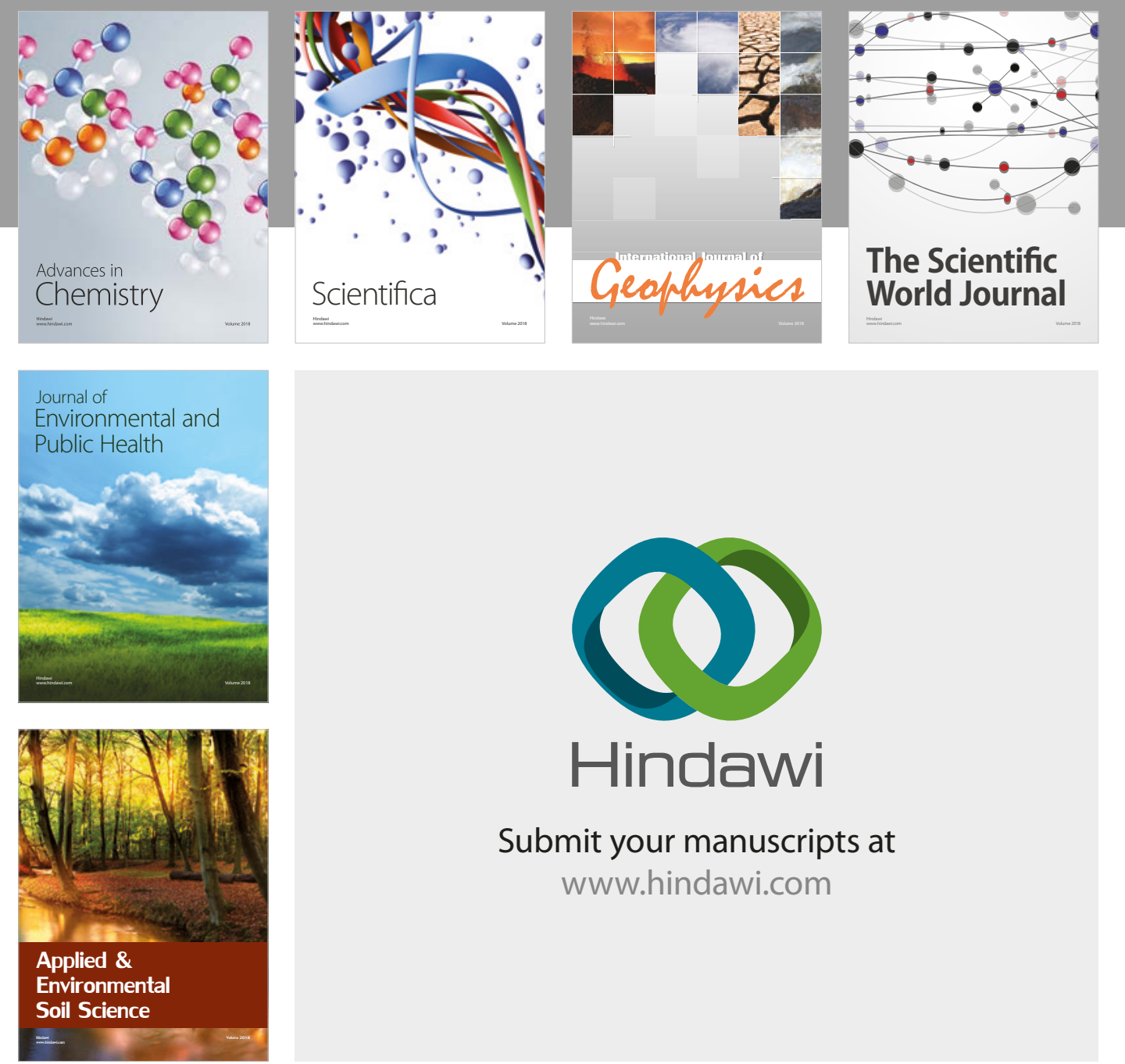

The Scientific

\section{World Journal}
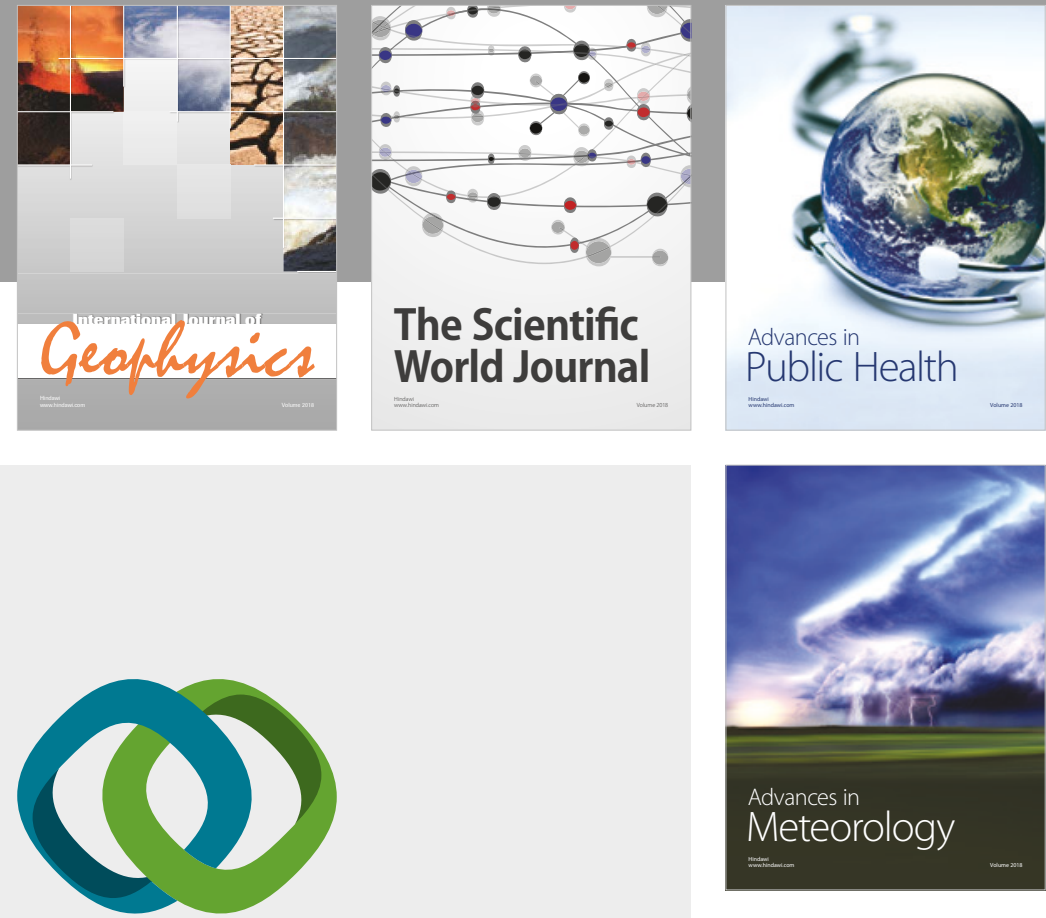

Advan

Public Health

\section{Hindawi}

Submit your manuscripts at

www.hindawi.com
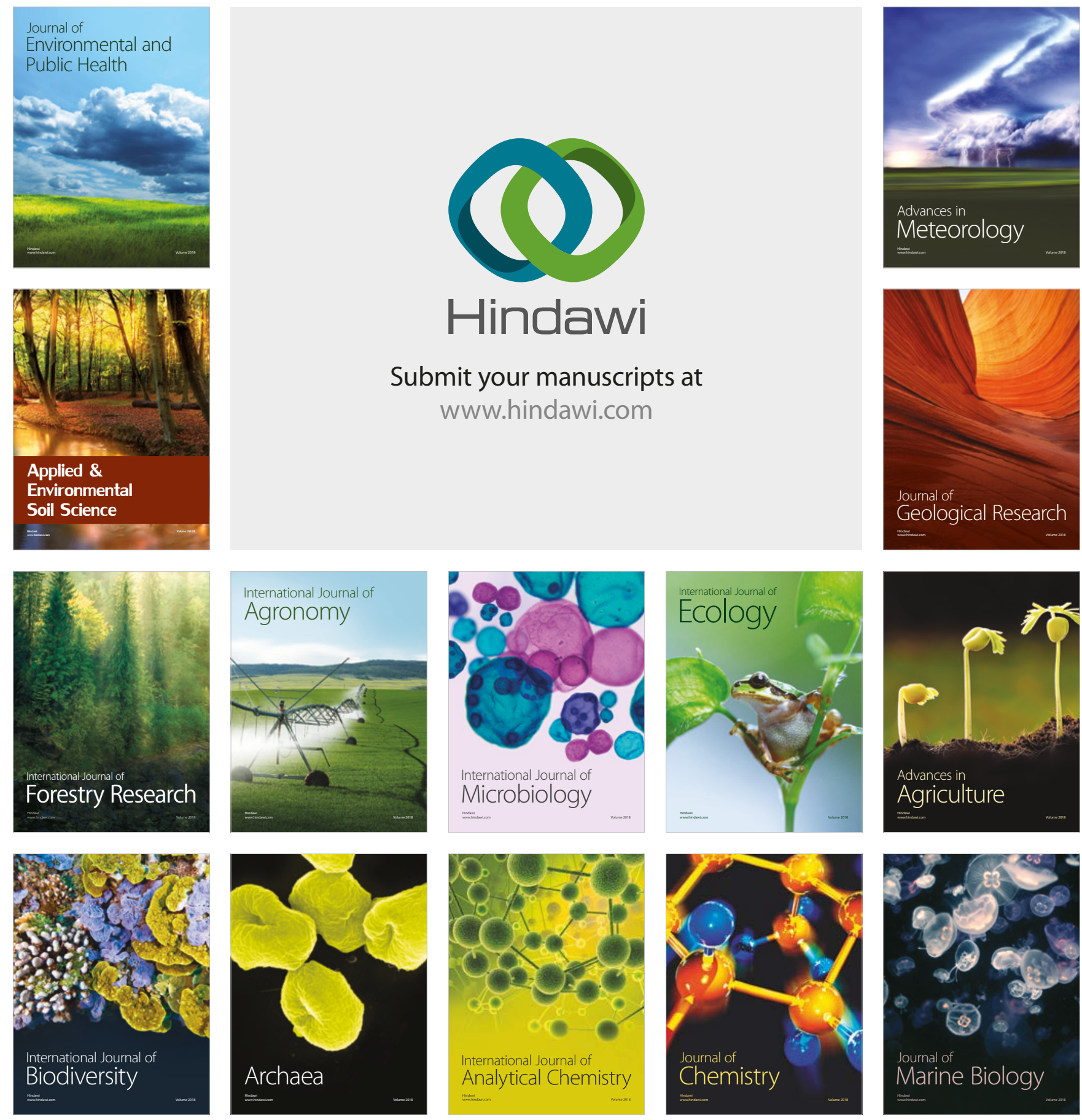